\title{
Chlorine nitrate in the atmosphere
}

\author{
Thomas von Clarmann and Sören Johansson \\ Karlsruhe Institute of Technology, Institute of Meteorology and Climate Research, Karlsruhe, Germany \\ Correspondence: Thomas von Clarmann (thomas.clarmann@kit.edu)
}

Received: 7 June 2018 - Discussion started: 5 July 2018

Revised: 25 September 2018 - Accepted: 11 October 2018 - Published: 26 October 2018

\begin{abstract}
This review article compiles the characteristics of the gas chlorine nitrate and discusses its role in atmospheric chemistry. Chlorine nitrate is a reservoir of both stratospheric chlorine and nitrogen. It is formed by a termolecular reaction of $\mathrm{ClO}$ and $\mathrm{NO}_{2}$. Sink processes include gas-phase chemistry, photo-dissociation, and heterogeneous chemistry on aerosols. The latter sink is particularly important in the context of polar spring stratospheric chlorine activation. $\mathrm{ClONO}_{2}$ has vibrational-rotational bands in the infrared, notably at $779,809,1293$, and $1735 \mathrm{~cm}^{-1}$, which are used for remote sensing of $\mathrm{ClONO}_{2}$ in the atmosphere. Midinfrared emission and absorption spectroscopy have long been the only concepts for atmospheric $\mathrm{ClONO}_{2}$ measurements. More recently, fluorescence and mass spectroscopic in situ techniques have been developed. Global $\mathrm{ClONO}_{2}$ distributions have a maximum at polar winter latitudes at about 20-30 km altitude, where mixing ratios can exceed 2 ppbv. The annual cycle is most pronounced in the polar stratosphere, where $\mathrm{ClONO}_{2}$ concentrations are an indicator of chlorine activation and de-activation.
\end{abstract}

\section{Introduction}

The species $\mathrm{NO}_{3} \mathrm{Cl}$ was first discovered by Martin and Jacobson in 1955 and called "nitroxyl chloride" (Martin and Jacobsen, 1955; Martin, 1958). In the literature of atmospheric sciences, this species is usually written $\mathrm{ClONO}_{2}$ or $\mathrm{ClNO}_{3}$ and called "chlorine nitrate", although it can be challenged if this species is indeed rightly called a "nitrate". It is also known as "chloro nitrate", "nitryl hypochlorite", or "nitroxyl chloride". It is a stratospheric species and acts as a reservoir of both reactive chlorine and nitrogen. In polar spring it is involved in heterogenic reactions in the stratosphere that release active chlorine, which destroys ozone.

\section{History}

Rowland et al. (1976) proposed the existence of $\mathrm{ClONO}_{2}$ in the stratosphere. The first observations of this species were reported by Murcray et al. (1977), who used a balloonborne mid-infrared solar occultation spectrometer. The spectral region near $780 \mathrm{~cm}^{-1}$ was used for analysis. These authors mentioned the possibility of $\mathrm{ClONO}_{2}$ being a chlorine reservoir but then could only infer upper limits from their measurements. Improved measurements by the same group (Murcray et al., 1979), now in the $1292 \mathrm{~cm}^{-1}$ spectral region, allowed the first retrieval of a vertical $\mathrm{ClONO}_{2}$ profile. In order to better constrain the knowledge of stratospheric chemistry, further balloon-borne solar occultation measurements were carried out (Rinsland et al., 1985; Payan et al., 1998; Toon et al., 1999). In addition, solar absorption measurements of $\mathrm{ClONO}_{2}$ were performed from aircraft (Mankin and Coffey, 1989; Mankin et al., 1990; Toon et al., 1992). The discovery of the ozone hole in the Antarctic (Chubachi, 1984b; Farman et al., 1985) had shifted the research interest towards polar latitudes, but solar absorption measurements, requiring sunlight, were not adequate to monitor related trace gases in the polar night. Emission spectroscopy was developed as an alternative observational technique (Fischer et al., 1983; Brasunas et al., 1986), and the first measurements of nighttime profiles of $\mathrm{ClONO}_{2}$ were reported by von Clarmann et al. (1993), who used measurements recorded by a balloon-borne limb infrared emission spectrometer. In the following, $\mathrm{ClONO}_{2}$ infrared emission measurements were also made from aircraft (Blom et al., 1995; Glatthor et al., 1998). Since then, numerous balloon-borne and aircraft missions provided $\mathrm{ClONO}_{2}$ measurements.

The thus-recognized importance of this gas triggered spectroscopic laboratory measurements with the goal of improv- 
ing its absorption cross sections (e.g., Ballard et al., 1988; Birk and Wagner, 2000).

$\mathrm{ClONO}_{2}$ was first measured from space in solar occultation with the Atmospheric Trace Molecule Spectroscopy (ATMOS) instrument, first from Spacelab 3 and later from further space shuttle missions (Zander et al., 1986; Rinsland et al., 1994). Further spaceborne solar occultation measurements were made with the Improved Limb Atmospheric Spectrometer (ILAS and ILAS-II) on the Advanced Earth Observing Satellite (ADEOS and ADEOS-II) (Nakajima et al., 2006; Hayashida et al., 2007; Griesfeller et al., 2008) and the Atmospheric Chemistry Experiment-Fourier Transform Spectrometer (ACE-FTS) on SciSat (e.g., Wolff et al., 2008). The first global $\mathrm{ClONO}_{2}$ measurements in limb emission were made with the Cryogenic Limb Array Etalon Spectrometer (CLAES) on the Upper Atmosphere Research Satellite (UARS) (Roche et al., 1993, 1994). Another spaceborne mission to measure $\mathrm{ClONO}_{2}$ limb emission was the Cryogenic Infrared Spectrometers and Telescopes for the Atmosphere (CRISTA) instrument (Riese et al., 1997, 1999). The Michelson Interferometer for Passive Atmospheric Sounding (MIPAS) provided the first long-term spaceborne measurements with global coverage of this reservoir gas. Being a limb emission instrument, it provided data also for polar night regions (Höpfner et al., 2004). After an instrument failure in 2004 the MIPAS measurement allowed only measurements at reduced spectral resolution, but $\mathrm{ClONO}_{2}$ could still be measured (von Clarmann et al., 2009). Thermal dissociation/resonance fluorescence was the first in situ technique to measure $\mathrm{ClONO}_{2}$ (http://airbornescience.nasa.gov/ instrument/ClONO2, last access: 23 January 2017). Mass spectroscopy is now also used for in situ detection of $\mathrm{ClONO}_{2}$ (Marcy et al., 2005; Jurkat et al., 2016).

Remote sensing of $\mathrm{ClONO}_{2}$ from the ground relies entirely on high-resolution Fourier transform spectrometry. The first ground-based measurements of this reservoir gas are reported by Zander and Demoulin (1988). The measurement site was Jungfraujoch in the Swiss Alps, and its high elevation was advantageous for the measurements because the measured light does not pass through the humid boundary layer, yielding a much clearer spectral signature of $\mathrm{ClONO}_{2}$. Today this gas is routinely measured for monitoring purposes from stations cooperating in the framework of the Network for Detection of Atmospheric Composition Change (NDACC) (e.g., Reisinger et al., 1995; Rinsland et al., 2003; Kohlhepp et al., 2011; De Maziére et al., 2018).

Summaries of stratospheric chlorine chemistry and its history are given by, e.g., Brasseur and Solomon (2005) and von Clarmann (2013).

\section{The geometrical structure}

While $\mathrm{ClONO}_{2}$ is a yellowish liquid at surface conditions below $295.5 \mathrm{~K}$, in the stratosphere it is a trace gas with a

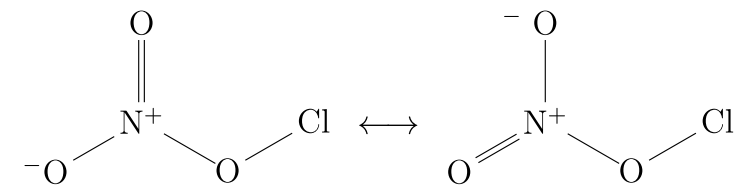

Figure 1. The chemical structure of chlorine nitrate.

significant role in chlorine-related chemistry. Its molar mass is $97.46 \mathrm{~g} \mathrm{~mol}^{-1}$. The structure of chlorine nitrate is shown in Fig. 1. Tables 1 and 2 show the bond angles and bond lengths.

\section{Sources}

In the atmosphere, chlorine nitrate is formed by a threebody reaction of chlorine monoxide $(\mathrm{ClO})$, nitrogen dioxide $\left(\mathrm{NO}_{2}\right)$, and a third body $(\mathrm{M})$ that is required to deactivate the activated complex of $\mathrm{ClO}$ and $\mathrm{NO}_{2}$, which otherwise would immediately decompose to $\mathrm{ClO}$ and $\mathrm{NO}_{2}$ (for details, see, e.g., Brasseur and Solomon, 2005, chap. 2.4.3, or Rowland et al., 1976).

$\left(k_{1}\right) \mathrm{ClO}+\mathrm{NO}_{2}+\mathrm{M} \longrightarrow \mathrm{ClONO}_{2}+\mathrm{M}$

While $\mathrm{ClO}$ is a radical which is directly involved in ozone destruction, the resulting $\mathrm{ClONO}_{2}$ is harmless for the ozone layer until the chlorine atoms are released again through heterogeneous reactions on polar stratospheric clouds in the polar winter vortex (see Sect. 5.3). Species which bind reactive chlorine are called "chlorine reservoir species", as opposed to "source gases" or "active chlorine". "Source gas" is an overarching term for more or less stable species which are released at the Earth's surface and transported into the stratosphere. "Active chlorine" designates the radicals which are directly involved in ozone destruction.

The currently recommended value for rate coefficient $k_{1}$ as a function of temperature $T$ is based on a low-pressure limit of

$k_{1 ; 0}=1.8 \times 10^{-31}\left(\frac{T}{300}\right)^{-3.4}$,

where laboratory measurements from Zahniser et al. (1977), Birks et al. (1977), Lee et al. (1982), Leu (1984), Wallington and Cox (1986), Cox and Hayman (1988), and Molina et al. (1980) were accommodated. The corresponding highpressure limit is based on calculations by Golden and Smith (2000), who used the Rice-Ramsberger-KasselMarcus (RKKM) theory of chemical reactivity (Rice and Ramsperger, 1927; Kassel, 1928; Marcus, 1952):

$k_{1 ; \text { inf }}=1.5 \times 10^{-11}\left(\frac{T}{300}\right)^{-1.9}$. 
Table 1. Bond angles of $\mathrm{ClONO}_{2}$, from Rankin and Robertson (1994).

\begin{tabular}{ll}
\hline Involved atoms & Value \\
\hline $\mathrm{Cl}-\mathrm{O}-\mathrm{N}$ & $113^{\circ}$ \\
$\mathrm{O}-\mathrm{N}-\mathrm{O}$ & $118.7^{\circ}$ \\
& $108.8^{\circ}$ \\
& $132.6^{\circ}$ \\
\hline
\end{tabular}

Table 2. Bond lengths of $\mathrm{ClONO}_{2}$, from Rankin and Robertson (1994).

\begin{tabular}{ll}
\hline Between nuclei of & Value \\
\hline $\mathrm{Cl}-\mathrm{O}$ & $167.3 \mathrm{pm}$ \\
$(\mathrm{Cl}-\mathrm{O})-\mathrm{N}$ & $149.9 \mathrm{pm}$ \\
$\mathrm{NO}$ & $119.6 \mathrm{pm}$ \\
\hline
\end{tabular}

With these, the pressure- and temperature-dependent rate coefficient can be estimated as a quasi bi-molecular rate coefficient as (Burkholder et al., 2015)

$$
\begin{aligned}
& k_{1}([M], t)= \\
& \quad\left(\frac{k_{1,0}(T)[M]}{1+\frac{k_{1,0}(T)[M]}{k_{1, \text { inf }}(T)}}\right) 0.6\left(1+\left(\log _{10}\left(\frac{k_{1,0}(T)[M]}{k_{1, \text { inf }}(T)}\right)\right)^{2}\right)^{-1} .
\end{aligned}
$$

\section{Sinks}

The sinks of $\mathrm{ClONO}_{2}$ are photolysis, gas-phase reactions, and heterogeneous reactions.

\subsection{Photolysis}

$\mathrm{ClONO}_{2}$ is photolyzed by radiation of wavelengths between 196 and $432 \mathrm{~nm}$. The temperature-dependent absorption cross sections currently recommended by Burkholder et al. (2015) have been measured by Burkholder et al. (1994). The absorption cross-section spectra for 200, 250, and $296 \mathrm{~K}$ are shown in Fig. 2.

The photodissociation can lead to different products. The first photolysis channel is

$\mathrm{ClONO}_{2}+h v \longrightarrow \mathrm{Cl}+\mathrm{NO}_{3}$.

For this reaction, Burkholder et al. (2015) recommend the following wavelength-dependent quantum yield $\Phi_{1}$ :

$$
\begin{array}{ll}
\Phi_{1}=0.6 & (\lambda<308 \mathrm{~nm}), \\
\Phi_{1}=7.143 \times 10^{-3} \lambda-1.60 & (308 \mathrm{~nm}<\lambda<364 \mathrm{~nm}), \\
\Phi_{1}=1.0 & (\lambda>364 \mathrm{~nm}),
\end{array}
$$

where $\lambda$ is the wavelength in nanometers. The second channel is

$\mathrm{ClONO}_{2}+h v \longrightarrow \mathrm{ClO}+\mathrm{NO}_{2}$,

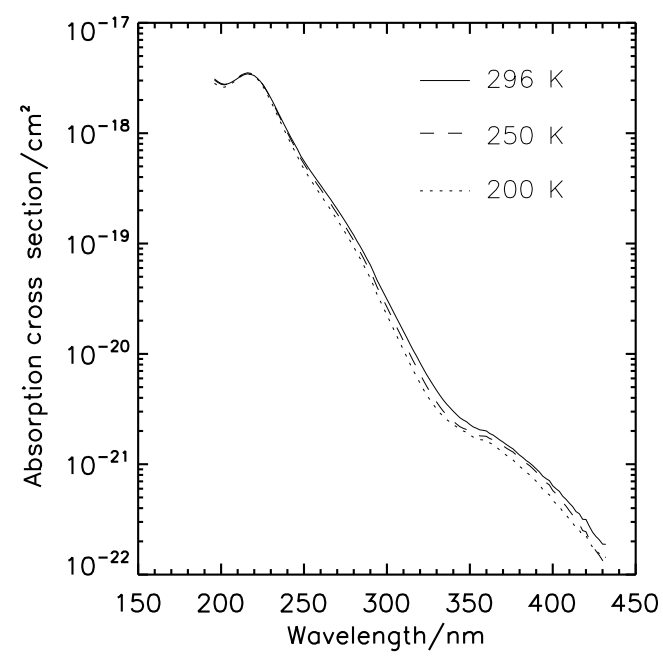

Figure 2. $\mathrm{ClONO}_{2} \mathrm{UV}$ absorption cross sections at $200 \mathrm{~K}$ (dotted), $250 \mathrm{~K}$ (dashed), and $296 \mathrm{~K}$ (solid).

and its recommended quantum yield $\Phi_{2}$ is $1-\Phi_{1}$. In earlier work a third channel was postulated (Brasseur and Solomon, 2005), namely

$\mathrm{ClONO}_{2}+h v \longrightarrow \mathrm{ClONO}+\mathrm{O}$.

In the most recent JPL recommendation on kinetic data (Burkholder et al., 2015), however, it is stated that there is no evidence of any relevance of this channel. The recommended quantum yields are based on work by Nelson et al. (1996), Moore et al. (1995), Nickolaisen et al. (1996), and Ravishankara (1995).

\subsection{Gas-phase reactions}

The most important gas-phase loss reactions of $\mathrm{ClONO}_{2}$ are (Brasseur and Solomon, 2005)

(k2) $\mathrm{ClONO}_{2}+\mathrm{O} \longrightarrow$ products

(k3) $\mathrm{ClONO}_{2}+\mathrm{Cl} \longrightarrow \mathrm{Cl}_{2}+\mathrm{NO}_{3}$

(k4) $\mathrm{ClONO}_{2}+\mathrm{OH} \longrightarrow \mathrm{HOCl}+\mathrm{NO}_{3}$.

Although no photons are explicitly involved in Reactions (R5)-(R7), these sinks have an implicit dependence on sunlight, because the reactants have a diurnal cycle themselves and are more abundant in the sunlit atmosphere. The related rate coefficients $k_{i}$ are temperature dependent, as described by the Arrhenius (1889) formalism:

$k(T)=A \exp -\frac{E / R}{T}$.

The pre-exponential Arrhenius factors and the so-called "activation temperatures" $E / R$, where $E$ is the activation energy and $R$ the gas constant, are listed in Table 3. 
Table 3. Rate constants of bi-molecular gas-phase sinks of $\mathrm{ClONO}_{2}$. The Arrhenius factors $A$ are given in units of $\mathrm{cm}^{3}$ molecule $\mathrm{s}^{-1} \mathrm{~s}^{-1}$. The temperature dependence $E / R$ (activation energy over universal gas constant) is given in units of kelvin. The values are taken from Burkholder et al. (2015).

\begin{tabular}{llrrl}
\hline Reaction & $\begin{array}{l}\text { Rate } \\
\text { coefficient }\end{array}$ & $A$ & $E / R$ & Reference \\
\hline R5 & $k_{2}$ & $3.6 \times 10^{-12}$ & 840 & $\begin{array}{l}\text { Goldfarb et al. (1998), } \\
\text { Molina et al. (1977), }\end{array}$ \\
R6 & $k_{3}$ & $6.5 \times 10^{-12}$ & -135 & $\begin{array}{l}\text { Kurylo (1977) } \\
\text { Yokelson et al. (1995), } \\
\text { Margitan (1983) }\end{array}$ \\
R7 & $k_{4}$ & $1.2 \times 10^{-12}$ & 330 & \begin{tabular}{l} 
Zahniser et al. (1977) \\
\hline
\end{tabular} \\
\hline
\end{tabular}

Further gas-phase sinks are listed in Burkholder et al. (2015) but are reported to be too slow to have any significant effect on atmospheric chemistry:

$$
\mathrm{H}_{2} \mathrm{O}+\mathrm{ClONO}_{2} \longrightarrow \text { products }
$$

(k6) $\mathrm{HCl}+\mathrm{ClONO}_{2} \longrightarrow$ products.

\subsection{Heterogeneous reactions}

The medium for heterogeneous reactions of $\mathrm{ClONO}_{2}$ is predominantly polar stratospheric clouds (PSCs), which form only in particularly cold polar winter vortices. Drdla and Müller (2012) also highlight the relevance of cold binary aerosol particles. These reactions reactivate the inorganic chlorine which is available in the form of chlorine reservoir species $\mathrm{HCl}$ and $\mathrm{ClONO}_{2}$. Størmer $(1929,1932)$ was the first to observe stratospheric clouds. These observations were a side effect of observations of the aurora borealis. The altitude of these clouds was estimated at $21-25 \mathrm{~km}$ altitude. The first spaceborne PSC measurements were made with the Stratospheric Aerosol Measurement II (SAM-II) on the Nimbus-7 satellite (McCormick et al., 1982). The role of heterogeneous reactions on surfaces of cloud particles in the explanation of the Antarctic ozone hole was first discussed by Solomon et al. (1986), suggesting the relevance of Reaction (R10). It was found that cold temperatures in the history of the air parcel were essential for chlorine activation, i.e., for the release of reactive chlorine from its reservoirs. The heterogeneous reactions of $\mathrm{ClONO}_{2}$ relevant for chlorine activation (see Sect. 6.2) are (Molina et al., 1987; Tolbert et al., 1987, 1988; Hanson and Ravishankara, 1991a, 1992b, 1993a)

$$
\begin{array}{r}
\mathrm{ClONO}_{2 \text { (gas) }}+\mathrm{HCl}_{\text {(solid,liquid) }} \\
\longrightarrow \mathrm{Cl}_{2 \text { (gas) }}+\mathrm{HNO}_{3 \text { (solid) }} \\
\mathrm{ClONO}_{2 \text { (gas) }}+\mathrm{HBr}_{\text {(solid,liquid) }} \\
\longrightarrow \mathrm{BrCl}_{\text {gas }}+\mathrm{HNO}_{3}
\end{array}
$$

$$
\begin{gathered}
\mathrm{ClONO}_{2 \text { (gas) }}+\mathrm{H}_{2} \mathrm{O}_{\text {(liquid,solid) }} \\
\longrightarrow \mathrm{HOCl}_{(\text {gas })}+\mathrm{HNO}_{3} .
\end{gathered}
$$

The product $\mathrm{HOCl}$ is a short-lived chlorine reservoir in itself and releases $\mathrm{Cl}_{2}$ via heterogeneous reaction with $\mathrm{HCl}$. The product $\mathrm{Cl}_{2}$ is photolyzed by sunlight in polar spring to give atomic $\mathrm{Cl}$, which is involved in catalytic ozone destruction.

Such heterogeneous reactions are typically modeled as pseudo-first-order reactions, where the reaction rate depends only on the concentration of the reactant and a rate coefficient (Brasseur and Solomon, 2005):

$$
\frac{\mathrm{d}\left[\mathrm{ClONO}_{2}\right]}{\mathrm{d} t}=-k \mathrm{ClONO}_{2} \text {. }
$$

$t$ is time and brackets indicate concentrations. The rate coefficient $k$ of the respective heterogeneous reaction is

$k=\frac{\gamma \bar{c} A}{4}$.

$\gamma$ is the surface reaction probability. Its values are tabulated in Table 4. $A$ is the surface area density of the aerosol, and $\bar{c}$ is the mean thermal speed of a $\mathrm{ClONO}_{2}$ molecule. It is calculated as

$\bar{c}=\sqrt{\frac{8 k_{\mathrm{B}} T}{\pi m}}$,

where $k_{\mathrm{B}}$ is the Boltzmann constant, $T$ is temperature, and $m$ is the molecular mass of $\mathrm{ClONO}_{2}$.

Heterogeneous reactions of $\mathrm{ClONO}_{2}$ on other surfaces have been investigated, e.g., by Hanson and Ravishankara (1991b), Hanson and Lovejoy (1995), and Ball et al. (1998) for sulfuric acid solutions; Finlayson-Pitts et al. (1989) for $\mathrm{NaCl}$ particles; Berko et al. (1991) for $\mathrm{NaBr}$ particles; and Molina et al. (1997) for aluminum oxide. The reader is referred to Burkholder et al. (2015) for a compilation of related reaction probabilities. In addition, hydrolysis reactions of $\mathrm{ClONO}_{2}$ on $\mathrm{TiO}_{2}$ and $\mathrm{SiO}_{2}$ surfaces have been investigated by Tang et al. (2016).

\section{The role of $\mathrm{ClONO}_{2}$ in atmospheric chemistry}

\section{1 $\mathrm{ClONO}_{2}$ as a stratospheric chlorine reservoir}

Chlorine source gases - chiefly $\mathrm{CH}_{3} \mathrm{Cl}$, CFC-12, CFC-11, $\mathrm{CCl}_{4}, \mathrm{HCFC}-22$, and $\mathrm{CH}_{3} \mathrm{CCl}_{3}$ - are decomposed in the stratosphere by photolysis, $\mathrm{OH}$ chemistry, or $\mathrm{O}^{1} \mathrm{D}$ chemistry and finally release chlorine radicals $\mathrm{Cl}$ or $\mathrm{ClO}$. These reactive chlorine species in principle have the potential to destroy large amounts of ozone via the the catalytic reaction cycle (Stolarski and Cicerone, 1974; Molina and Rowland, 1974):

$\mathrm{Cl}+\mathrm{O}_{3} \longrightarrow \mathrm{ClO}+\mathrm{O}_{2}$

$\mathrm{ClO}+\mathrm{O} \longrightarrow \mathrm{Cl}+\mathrm{O}_{2}$ 
Table 4. Relevant surface reaction probabilities as recommended by Burkholder et al. (2015). Their document contains reaction probabilities for further surfaces not mentioned here.

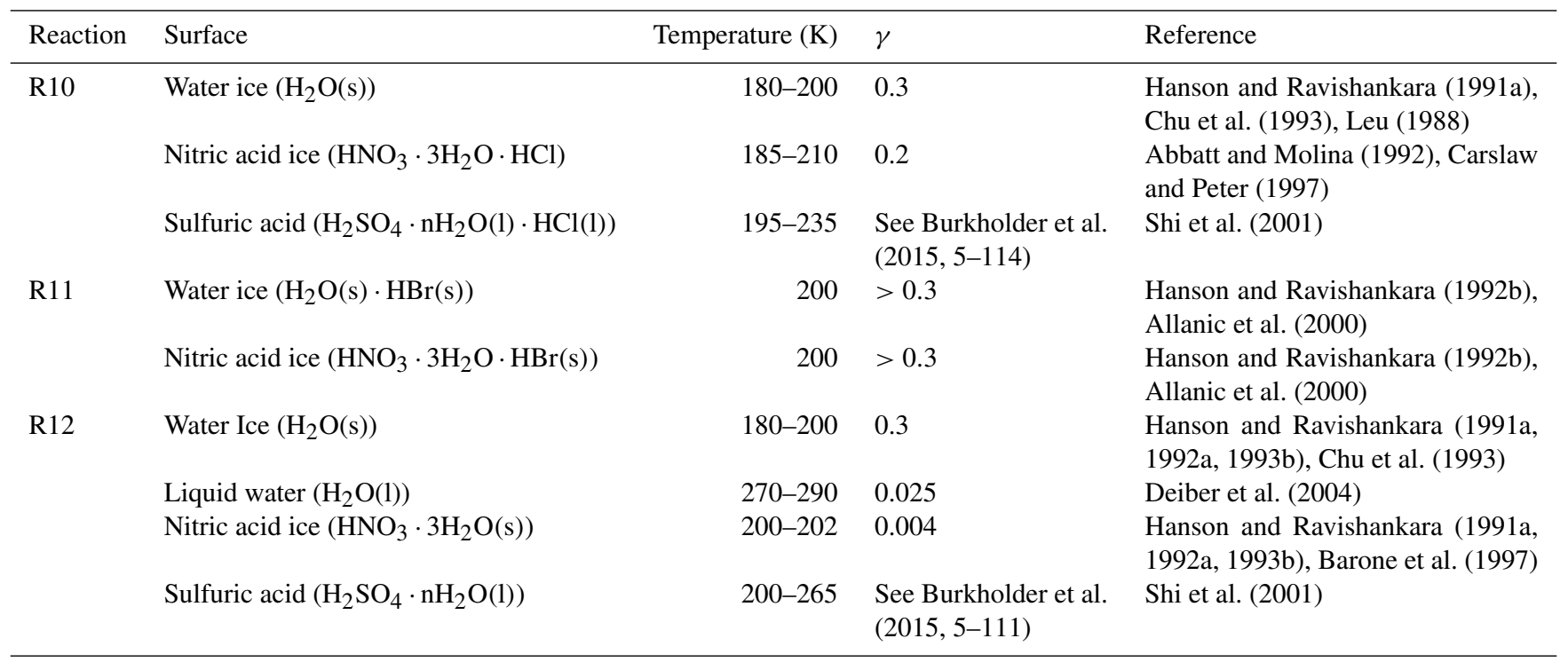

net : $\mathrm{O}_{3}+\mathrm{O} \longrightarrow 2 \mathrm{O}_{2}$.

In the lower stratosphere, however, the equilibrium of $\mathrm{O}$ and $\mathrm{O}_{3}$ is shifted massively towards the latter, making the above $\mathrm{ClO}_{x}$ cycle inefficient due to the lack of atomic oxygen (Salawitch et al., 1993; Molina, 1996). Here, the following so-called "dimer cycle" gains relevance (Molina and Molina, 1987; Cox and Hayman, 1988; Barrett et al., 1988; Anderson et al., 1989):

$2 \times\left(\mathrm{Cl}+\mathrm{O}_{3} \longrightarrow \mathrm{ClO}+\mathrm{O}_{2}\right)$

$\mathrm{ClO}+\mathrm{ClO}+\mathrm{M} \longrightarrow \mathrm{Cl}_{2} \mathrm{O}_{2}+\mathrm{M}$

$\mathrm{Cl}_{2} \mathrm{O}_{2}+h v \longrightarrow \mathrm{ClOO}+\mathrm{Cl}$

$\mathrm{ClOO}+\mathrm{M} \longrightarrow \mathrm{Cl}+\mathrm{O}_{2}+\mathrm{M}$

net : $2 \mathrm{O}_{3}+h v \longrightarrow 3 \mathrm{O}_{2}$.

Similarly, the coupled catalytic cycle involving also bromine radicals $\mathrm{Br}$ and $\mathrm{BrO}$ is also independent of atomic oxygen (Yung et al., 1980; McElroy et al., 1986b; Barrett et al., 1988).

$\mathrm{Cl}+\mathrm{O}_{3} \longrightarrow \mathrm{ClO}+\mathrm{O}_{2}$

$\mathrm{Br}+\mathrm{O}_{3} \longrightarrow \mathrm{BrO}+\mathrm{O}_{2}$

$\mathrm{ClO}+\mathrm{BrO} \longrightarrow \mathrm{Br}+\mathrm{ClOO}$

$\mathrm{ClOO}+\mathrm{M} \longrightarrow \mathrm{Cl}+\mathrm{O}_{2}+\mathrm{M}$

net : $2 \mathrm{O}_{3} \longrightarrow 3 \mathrm{O}_{2}$

Under normal conditions, these catalytic cycles are much less disastrous than one might think. The reason is that usually not all of the reactive chlorine released from the chlorine source gases is available for ozone destruction. Instead, reaction of the chlorine radicals with other atmospheric species binds them, forming so-called reservoir gases, which are relatively inert (Rowland et al., 1976; Zahniser et al., 1977; Birks et al., 1977). $\mathrm{HCl}$ and $\mathrm{ClONO}_{2}$ are the most important chlorine reservoir gases in the atmosphere. The latter is formed by Reaction (R1). The importance of these reservoirs not only consists of the temporary deactivation of reactive chlorine but also allows chlorine to be transported over long distances without reaction. Release of reactive chlorine from its reservoirs is essential to understanding stratospheric chemistry. In the case of chlorine nitrate, the heterogeneous Reactions (R10)-(R12) are particularly important release reactions. After finding evidence of $\mathrm{ClONO}_{2}$ in the stratosphere, Murcray et al. (1977) were the first to suggest that $\mathrm{ClONO}_{2}$ can act as a chlorine reservoir.

There exists, however, a catalytic ozone destruction cycle which involves $\mathrm{ClONO}_{2}$ (Toumi et al., 1993). Its importance lies in the fact that there exists a $\mathrm{ClONO}_{2}$ photolysis pathway which generates atomic chlorine.

$$
\begin{aligned}
& \mathrm{ClO}+\mathrm{NO}_{2}+\mathrm{M} \longrightarrow \mathrm{ClONO}_{2}+\mathrm{M} \\
& \mathrm{ClONO}_{2}+h v_{1} \longrightarrow \mathrm{Cl}+\mathrm{NO}_{3} \\
& \mathrm{Cl}+\mathrm{O}_{3} \longrightarrow \mathrm{ClO}+\mathrm{O}_{2} \\
& \mathrm{NO}_{3}+h v_{2} \longrightarrow \mathrm{NO}+\mathrm{O} 2 \\
& \frac{\mathrm{NO}+\mathrm{O}_{3} \longrightarrow \mathrm{NO}_{2}+\mathrm{O}_{2}}{2 \mathrm{O}_{3}+h v_{1}+h v_{2} \longrightarrow 3 \mathrm{O}_{2}}
\end{aligned}
$$

Further catalytic cycles exist, involving $\mathrm{HO}_{x}$ and $\mathrm{NO}_{x}$ chemistry (Hampson, 1964; Crutzen, 1970).

\section{2 $\mathrm{ClONO}_{2}$ and polar stratospheric ozone chemistry}

The detection of the Antarctic ozone hole by Chubachi (1984a) and Farman et al. (1985) puzzled the scientific com- 
munity. This massive destruction of ozone in the lower polar spring stratosphere begged for explanation, because it could be quantitatively reproduced neither with the chlorine cycles (Reactions R13-R15) nor similar cycles involving NO and $\mathrm{NO}_{2}$ or $\mathrm{OH}$ and $\mathrm{HO}_{2}$. Models predicted largest ozone destruction in the middle and upper stratosphere at midlatitudes where most reactive chlorine was expected due to the decomposition of chlorine source gases.

Ozone loss, however, was expected to be much weaker than the observed Antarctic ozone loss and to be not a seasonal but a steady phenomenon. Soon, the relevance of heterogeneous reactions to the release of reactive chlorine from its reservoirs was recognized (Solomon et al., 1986). Measurements of reduced amounts of $\mathrm{ClONO}_{2}$ and $\mathrm{HCl}$ (Farmer et al., 1987; Coffey et al., 1989; Toon et al., 1989) along with increased amounts of ClO (de Zafra et al., 1987; Solomon et al., 1987; Brune et al., 1989) supported this hypothesis. Re-appearance of sunlight after the polar night entailed photolysis of $\mathrm{Cl}_{2}$ resulting from the heterogeneous decomposition of $\mathrm{ClONO}_{2}$ (and similarly of $\mathrm{HOCl}$ resulting from the heterogeneous decomposition of $\mathrm{HCl}$ ). Largest lower-stratospheric $\mathrm{ClO}$ concentrations were indeed measured in sunlit air masses which had passed polar stratospheric clouds, allowing heterogeneous processing (Yudin et al., 1997). Since sunlight is essential for large ozone loss, the severity of an ozone hole depends largely on how long heterogeneous chlorine activation still competes with the reformation of reservoirs in spring when enough sunlight is available for keeping the catalytic cycles going. With the catalytic dimer cycle (Reactions R16-R20) a mechanism was available which did not depend on atomic oxygen, which is only available in sizeable amounts at higher altitudes than those of the ozone hole. With this, the puzzle of the seasonality and the altitude range of polar stratospheric ozone destruction was solved, and measured $\mathrm{ClO}$ concentrations and ozone loss could be modeled reasonably well under consideration of heterogeneous chlorine activation (Jones et al., 1989). Anderson et al. (1991) estimated the contribution of the $\mathrm{ClO}$ dimer cycle to Antarctic ozone destruction at about $75 \%$. For a more thorough summary of the history of ozone hole research and hypotheses suggested to explain this massive ozone depletion, see Solomon (1990), Brasseur and Solomon (2005), Solomon (1999), or von Clarmann (2013). An updated view on polar ozone chemistry, including reactions involving sulfate aerosols as well, is presented by Solomon et al. (2015).

The re-formation of $\mathrm{ClONO}_{2}$ via Reaction (R1) would make the catalytic ozone destruction cycle (Reactions R16R20) less efficient. However, particles of polar stratospheric clouds can remove gaseous $\mathrm{HNO}_{3}$ from the air, which leads to reduced amounts of reactive nitrogen, viz $\mathrm{NO}$ and $\mathrm{NO}_{2}$ (McElroy et al., 1986a). Nitrogen compounds are irreversibly removed from altitudes where the cloud particles are formed through sedimentation of $\mathrm{HNO}_{3}$-laden particles grown by condensation (Toon et al., 1986; Salawitch et al., 1988).
This denitrification slows down re-formation of $\mathrm{ClONO}_{2}$ and thus has the potential to accelerate catalytic ozone destruction. While denitrification was indeed observed in polar winter vortices (Fahey et al., 1990; Toon et al., 1990; Deshler et al., 1991), it is not necessarily correlated with the depth of the ozone hole (Santee et al., 1998; Brasseur and Solomon, 2005). Denitrification in early winter goes along with dehydration of the stratosphere, which prevents sustained springtime heterogeneous chlorine reactivation (Portmann et al., 1996; Chipperfield and Pyle, 1998). This tends to counterbalance the effect of denitrification on chlorine activation and ozone destruction.

In summary and roughly speaking, interaction of the following processes brings about the ozone hole: in the cold polar winter vortex, where subsidence has brought air from higher altitudes rich in chlorine reservoirs down into the lower stratosphere, polar stratospheric clouds form, on the surfaces of which the chlorine reservoirs are broken up by heterogeneous reaction. Polar spring sunlight photolyzes the intermediate products and produces reactive chlorine which, chiefly via the $\mathrm{ClO}$ dimer cycle, destroys ozone. Denitrification contributes by removing reactive nitrogen and thus impedes efficient re-formation of $\mathrm{ClONO}_{2}$. More recent studies mention the importance of cold binary sulfate aerosol particles as the surface for heterogeneous chlorine activation besides polar stratospheric clouds (Drdla and Müller, 2012).

Antarctic and Arctic polar winter ozone depletion follows roughly the same mechanisms. The most pronounced differences are that the Arctic vortex is typically not as cold as its Antarctic counterpart, entailing less frequent occurrence of polar stratospheric clouds. Stratospheric final warmings occur typically earlier in the season than in the Antarctic, terminating chlorine activation on polar stratospheric clouds. Major and minor stratospheric warmings which interrupt chlorine activation temporarily are common in the Arctic but occur very rarely in Antarctic winters. Due to stronger wave activity in the Northern Hemisphere there are more frequent excursions of the polar vortex to sunlit lower latitudes.

Evidence of Arctic chlorine activation was furnished either by observations of $\mathrm{ClO}$ (Manney et al., 1994) or by measurement of largely reduced amounts of the reservoirs $\mathrm{HCl}$ and $\mathrm{ClONO}_{2}$ by ground-based mid-infrared spectrometry (e.g., Adrian et al., 1994; Blumenstock et al., 1997; Notholt et al., 1994, 1995). The differences in typical meteorological conditions discussed above lead to differences in chlorine deactivation in Antarctic versus Arctic spring. The lack of $\mathrm{NO}_{2}$ after denitrification rules out formation of sizeable amounts of $\mathrm{ClONO}_{2}$ in the Antarctic, and $\mathrm{HCl}$ is the chiefly formed reservoir there. Conversely, ozone is usually too high in the Arctic to allow efficient $\mathrm{HCl}$ formation, and denitrification is much less of an issue in the Arctic. In the sunlit atmosphere, $\mathrm{HNO}_{3}$ is photolyzed, and sufficient abundances of $\mathrm{NO}_{2}$ thus allow re-formation of $\mathrm{ClONO}_{2}$, which in some winters largely exceeds $\mathrm{HCl}$ formation (Müller et al., 1994; Adrian et al., 1994; Douglass et al., 1995; Rinsland et al., 


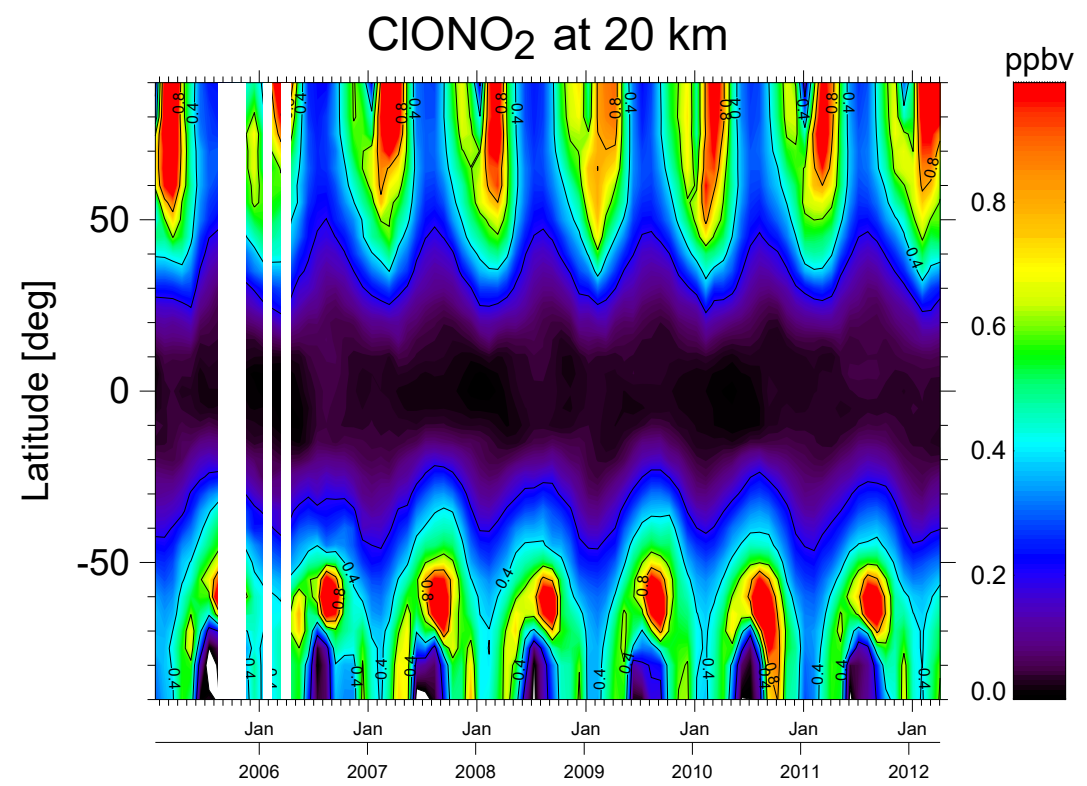

Figure 3. The temporal development of $\mathrm{ClONO}_{2}$ at $20 \mathrm{~km}$, based on MIPAS monthly mean mixing ratios. White stripes represent data gaps due to missing measurements. Figure from von Clarmann et al. (2009), used under CC Attribution 3.0 license.

1995; Santee et al., 1996; Payan et al., 1998; Santee et al., 2008). Huge amounts of $\mathrm{ClONO}_{2}$ in Arctic spring were measured by, e.g., von Clarmann et al. (1993, 1997), Roche et al. (1994), and Blom et al. (1995). A sensitivity study showing how PSC formation and denitrification affect $\mathrm{ClONO}_{2}$ and ozone chemistry is shown in Rex et al. (1997) in order to explain large Arctic ozone loss in the particularly cold winter of 1995/96.

Since $\mathrm{ClONO}_{2}$ formation depends on photolysis of $\mathrm{HNO}_{3}$, largest $\mathrm{ClONO}_{2}$ concentrations are found close to the edge of the Arctic vortex, while chlorine in the dark part of the vortex remains activated longer (e.g., Toon et al., 1992). In Fig. 3 the seasonal formation of $\mathrm{ClONO}_{2}$ at polar latitudes as seen by MIPAS can be clearly seen. Figure 4 shows MIPAS measurements of $\mathrm{ClONO}_{2}$ over the Arctic at $18 \mathrm{~km}$ altitude in March 2011. The "collar" of enhanced values, a phenomenon first described by Toon et al. (1989) and first attributed to mixing of vortex air rich in $\mathrm{ClO}$ with air from lower latitudes with larger $\mathrm{NO}_{2}$ concentrations, is clearly visible. More recent explanations of enhanced $\mathrm{ClONO}_{2}$ abundances in this region involve in situ deactivation of $\mathrm{ClO}$ with $\mathrm{NO}_{2}$ released from $\mathrm{HNO}_{3}$ in the sunlit part of the vortex, via either photolysis or OH chemistry (Chipperfield et al., 1997).

Volcanic eruptions such as that of Mount Pinatubo can cause large stratospheric aerosol loading (e.g., Browell et al., 1993). The role of this volcanic sulfate aerosol as a medium for heterogeneous reactions releasing reactive chlorine has been discussed by, e.g., Prather (1992), Brasseur (1992), O. B. Toon et al. (1993), Wilson et al. (1993), and Dessler et al. (1993). Borrmann et al. (1997), however, found that chlorine activation by heterogeneous reactions on volcanic

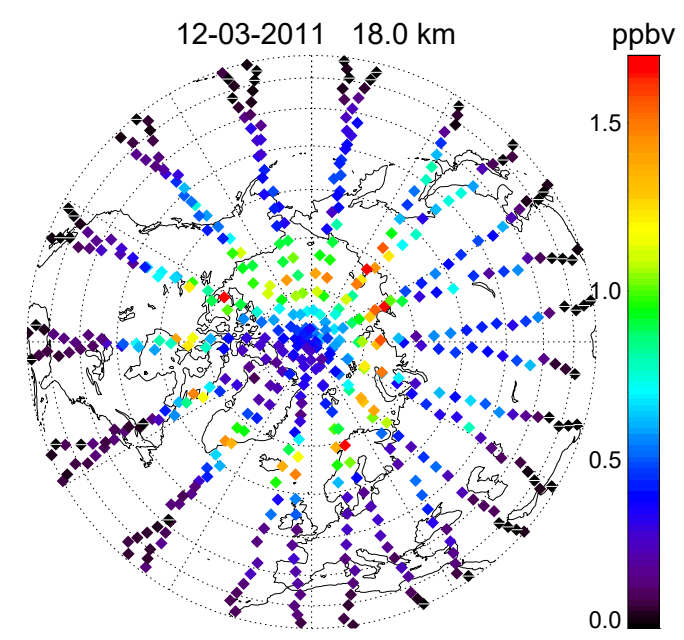

Figure 4. Chlorine nitrate measurements by MIPAS over the Arctic at $18 \mathrm{~km}$ altitude on 12 March 2011. The "collar" of large mixing ratios surrounds the core area of the polar vortex where $\mathrm{ClONO}_{2}$ values are lower. Figure from von Clarmann et al. (2009), used under CC Attribution 3.0 license.

cloud droplets is much less efficient than chlorine activation by polar stratospheric clouds. According to Cox et al. (1994), $\mathrm{ClONO}_{2}$ hydrolysis on sulfate aerosol can have sizeable effects if temperatures are below $190 \mathrm{~K}$, and a lot of aerosol particles are available. The role of sulfate aerosols for chlorine activation in polar vortices seems limited due to the predominant chlorine activation on polar stratospheric clouds. 


\section{3 $\mathrm{ClONO}_{2}$ and extra-polar stratospheric chlorine chemistry}

Polar stratospheric clouds are the most efficient but not the only medium to provide liquid or solid surfaces on which heterogeneous reactions can take place. At middle and low latitudes where temperatures are too high for the formation of polar stratospheric clouds, sulfate aerosol is the most likely candidate (Pitari et al., 1991). The aerosol cloud of the Mount Pinatubo eruption served as an ideal test case to investigate the role which sulfate aerosols play in midlatitudinal stratospheric ozone depletion (McCormick et al., 1995). Both in the tropical stratosphere (Grant et al., 1992) and globally (Randel et al., 1995), less ozone was found in the aerosolloaded atmosphere after the eruption. Weaver et al. (1993) could not corroborate this hypothesis because no correlations between ozone depletion and aerosol surface area density was found. Hofmann et al. (1994), however, found that low ozone concentrations were measured in air which came from high latitudes. There cold air along with the exponential decrease of the reaction probability of Reaction (R12) with temperature (Robinson et al., 1997) provided more favorable conditions for the hydrolysis of $\mathrm{ClONO}_{2}$. Wilson et al. (1993) and Avallone et al. (1993) indeed report enhanced $\mathrm{ClO}$ concentrations in air masses with higher aerosol loading. Chlorine activation was found to strongly depend on aerosol-loaded air being exposed to temperatures below $195 \mathrm{~K}$ (Kawa et al., 1997). Solomon et al. (2016) found chlorine activation on liquid sulfate aerosols near the northern monsoon regions in their model calculations.

Along with increased chlorine activation, reactive nitrogen is removed in the aerosol cloud (Fahey et al., 1993). It is for this reason that in the aerosol-loaded air after the Pinatubo eruption the chlorine catalytic cycle outweighed the nitrogen cycle and was second in efficiency only to the $\mathrm{HO}_{x}$ catalytic cycle (Kinnison et al., 1994). As described above for polar ozone chemistry, removal of $\mathrm{NO}_{2}$ via sequestering of $\mathrm{HNO}_{3}$ on aerosol leads to reduced re-formation of $\mathrm{ClONO}_{2}$ (Tie and Brasseur, 1996), and buildup of $\mathrm{HCl}$ gains importance as a reservoir re-formation process (Webster et al., 1998).

\section{4 $\mathrm{ClONO}_{2}$ and solar proton events}

Solar activity does affect atmospheric chemistry in multiple ways. In particular, the role of solar proton events has been studied. Most investigations focus on these events as a source of $\mathrm{NO}_{x}$ (e.g., Jackman et al., 1990), but Solomon and Crutzen (1981) highlight the importance of $\mathrm{ClO}_{x}$ chemistry in this context. The question is if solar proton events accelerate or decelerate ozone destruction by active chlorine. According to theoretical studies by Jackman et al. (2000), the increased abundance of $\mathrm{NO}_{x}$ would accelerate $\mathrm{ClONO}_{2}$ formation and thus reduce the amount of reactive chlorine and decelerate ozone destruction by $\mathrm{ClO}_{x}$. This hypothesis seemed to be refuted by von Clarmann et al. (2005), who, in
MIPAS data measured after the Halloween 2003 solar proton event, found increased amounts of $\mathrm{ClO}$ in the sunlit part of the polar vortex. Only in the dark part of the polar vortex poleward of $70^{\circ} \mathrm{N}$ was $\mathrm{ClO}$ observed to decrease (Funke et al., 2011). Damiani et al. (2012), however, found a negative response of $\mathrm{ClO}$ to the January 2005 solar proton event. This result is consistent with that of von Clarmann et al. (2005) insofar as protons in a sunlit atmosphere lead to chlorine activation, while protons in a dark atmosphere lead to chlorine de-activation via $\mathrm{ClONO}_{2}$ formation. Ionization rates of the solar proton event in 2012 were too small to cause significant $\mathrm{ClO}$ changes.

\section{5 $\mathrm{ClONO}_{2}$ in the polar troposphere and the marine boundary layer}

$\mathrm{ClONO}_{2}$ is predicted to be important in the springtime Arctic boundary layer ozone chemistry (Wang and Pratt, 2017). Via multiphase reaction it contributes to the generation of $\mathrm{Cl}_{2}$. Associated snowpack chemistry, however, is reported to be still poorly understood. In a model study by Sander et al. (1999), heterogeneous reactions of $\mathrm{ClONO}_{2}$ had only a negligible effect in the marine boundary layer.

\section{Spectroscopy}

As discussed in Sect. 5.1, $\mathrm{ClONO}_{2}$ makes a contribution to the absorption cross-section spectrum in the UV, where photolyzing radiation is absorbed. The UV absorption cross section for radiation of wavelengths between 196 and $432 \mathrm{~nm}$ is shown in Fig. 2.

The infrared spectrum of $\mathrm{ClONO}_{2}$ is only marginally resolved (Butler et al., 2007); thus measured absorption crosssection spectra are used instead of line parameters as a reference in atmospheric radiative transfer calculations. In the infrared spectral region, Birk and Wagner (2000) and Wagner and Birk (2003) measured the absorption cross section for $\mathrm{ClONO}_{2}$ in a laboratory study. They synthesized $\mathrm{ClONO}_{2}$ from nitrogen pentoxide $\left(\mathrm{N}_{2} \mathrm{O}_{5}\right)$ and dichlorine monoxide $\left(\mathrm{Cl}_{2} \mathrm{O}\right)$ under vacuum conditions into a gas cuvette and measured the absorption cross sections with a high-resolution Fourier transform spectrometer. The temperature range was 190-296 K and the pressure range $0-150 \mathrm{hPa}$. An example of these cross sections is shown in Fig. 5 for (a) $v_{4}\left(780 \mathrm{~cm}^{-1}\right)$ and $v_{3}\left(810 \mathrm{~cm}^{-1}\right)$ and (b) $v_{2}\left(1290 \mathrm{~cm}^{-1}\right)$. Worst-case relative errors are reported as ${ }_{-5.5}^{+4.5} \%$. These absorption cross sections are recommended for use in atmospheric research by the most recent version of the HITRAN (HIgh-resolution TRANsmission) spectral database (Gordon et al., 2017) and have been the recommendation since the 2004 version of HITRAN (Rothman et al., 2005).

A typical spectral signal of enhanced $\mathrm{ClONO}_{2}$ in the atmosphere is shown in Fig. 6. This measurement of MIPAS/Envisat (black line) during the Arctic springtime 2003 

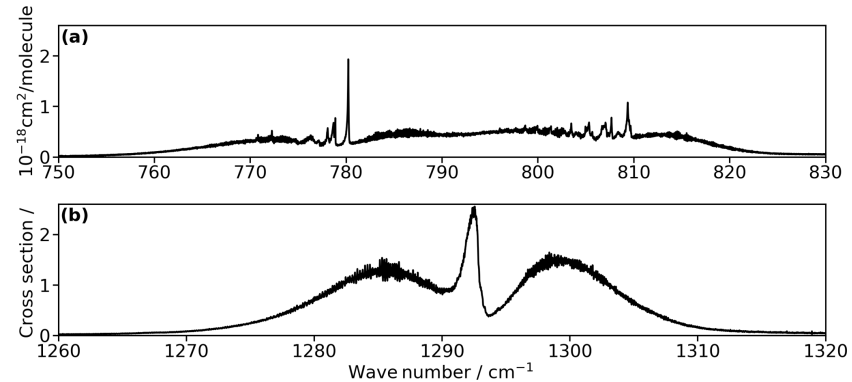

Figure 5. Example of an absorption cross section of $\mathrm{ClONO}_{2}$ (a) $v_{4}$ and $v_{3}$ and (b) $v_{2}$ bands, measured by Wagner and Birk (2003) in a cuvette at a temperature of $297.4 \mathrm{~K}$ and pressure of $100 \mathrm{hPa}$.

at a tangent altitude of $17.3 \mathrm{~km}$ corresponds to a retrieved volume mixing ratio of $2.3 \mathrm{ppbv}$ of $\mathrm{ClONO}_{2}$. In this spectral region of the $\mathrm{ClONO}_{2} v_{4}$ and $v_{3}$ band (see Fig. 6, red solid line), other atmospheric trace (mainly $\mathrm{O}_{3}$ and $\mathrm{CO}_{2}$ ) gases also have absorption features (see Fig. 6, colored lines).

Butler et al. (2007) try to understand the rotational structure of $\mathrm{ClONO}_{2}$ from measurements in the millimeter and sub-millimeter spectral regions where the transitions are better resolved and to apply this knowledge to the infrared bands. These activities are meant as one step towards lineby-line modeling of the infrared spectrum of $\mathrm{ClONO}_{2}$. The paper also summarizes existing high-resolution studies of the $\mathrm{ClONO}_{2}$ spectroscopy in the microwave and infrared regions, but these are of no direct relevance to atmospheric spectrometry yet.

\section{Measurement techniques}

\subsection{Remote sensing}

The only remote-sensing technique by which $\mathrm{ClONO}_{2}$ is measured is mid-infrared spectrometry. $\mathrm{ClONO}_{2}$ has suitable spectral bands at $779,809,1293$, and $1735 \mathrm{~cm}^{-1}$. The bands at lower wavenumbers are used both in emission and absorption geometry, while the bands at higher wavenumbers are used in absorption spectrometry only. By far the most common remote-sensing technique for $\mathrm{ClONO}_{2}$ is Fourier transform spectrometry (FTS). Some earlier measurements were made with grating spectrometers.

\subsubsection{Absorption spectrometry}

Earth observation by absorption spectroscopy uses a natural background light source. The most common source of radiation is the sun. Occasionally the moon is used (e.g., Notholt, 1994). Absorption of starlight has not yet been applied to $\mathrm{ClONO}_{2}$. The information is contained in the absorption of background radiance by atmospheric constituents. While the signal-to-noise ratio is superior to that of emission measurements and the temperature dependence of the signal is less of a problem, the major drawback of absorption spectrometry is that the feasibility of measurements depends on the astronomical conditions, since the line of sight of the measurement must hit the background source. Thus, solar absorption measurements are possible neither during night nor during polar winter.

\section{Ground-based solar absorption spectrometry}

Earliest ground-based solar absorption measurements of $\mathrm{ClONO}_{2}$ were made with high-resolution Michelson Fourier transform spectrometers at the International Scientific Station of the Jungfraujoch, Switzerland, in June 1986 (Zander and Demoulin, 1988). Measurements at this high altitude offer the advantage that the ray path usually does not cross the moist boundary layer, that the tropospheric column of interfering species is smaller, and that pressure broadening of interfering spectral lines is less relevant. Since the rotational structure and, a fortiori, pressure broadening are not resolved in the case of $\mathrm{ClONO}_{2}$, ground-based measurements provide no vertical profile information but rather only vertical column densities. The detection of the Antarctic ozone hole provided motivation to monitor relevant species, including $\mathrm{ClONO}_{2}$, also from ground. Farmer et al. (1987) measured Austral spring column amounts above McMurdo station with the MkIV interferometer ${ }^{1}$. Similarly, motivated by the desire to understand Arctic ozone chemistry and chlorine activation/deactivation and to identify its similarities with and differences to the Antarctic, ground-based measurements were performed at polar research stations in Ny-Ålesund, Spitsbergen (Notholt et al., 1994, 1995); Esrange, Kiruna, Sweden (Adrian et al., 1994; Blumenstock et al., 1997, 1998; Wegner et al., 1998; Blumenstock et al., 2006); Åre, Sweden (Bell et al., 1994); Harestua, Norway (Galle et al., 1999); St. Petersburg, Russia (Virolainen et al., 2015); and Eureka, Canada (Batchelor et al., 2010). Multiple-site observations (Ny-Ålesund, Kiruna, Haresuta) were reported by, e.g., Mellqvist et al. (2002). Given the strong excursions of the polar vortex, even measurements from Aberdeen, Scotland (Bell et al., 1998a, b), contributed to polar ozone research. The scientific goal of these $\mathrm{ClONO}_{2}$ measurements was to study chlorine activation and deactivation during polar winter. Early non-polar column measurements of $\mathrm{ClONO}_{2}$ were made with the ATMOS instrument from the Table Mountain Observatory, California (Gunson and Irion, 1991).

Later the research interest moved towards identification of multi-year regularities and time series (e.g., Rinsland et al., 1996b; Blumenstock et al., 2000; Reisinger et al., 1995; Notholt et al., 1997; Rinsland et al., 2003, 2010; Kohlhepp et al., 2011, 2012). Meanwhile worldwide monitoring of stratospheric $\mathrm{ClONO}_{2}$ is performed by the Network for Detection of Atmospheric Composi-

\footnotetext{
${ }^{1}$ Although Farmer et al. (1987) was published before Zander and Demoulin (1988), the measurements reported in the latter paper preceded those of the former paper.
} 


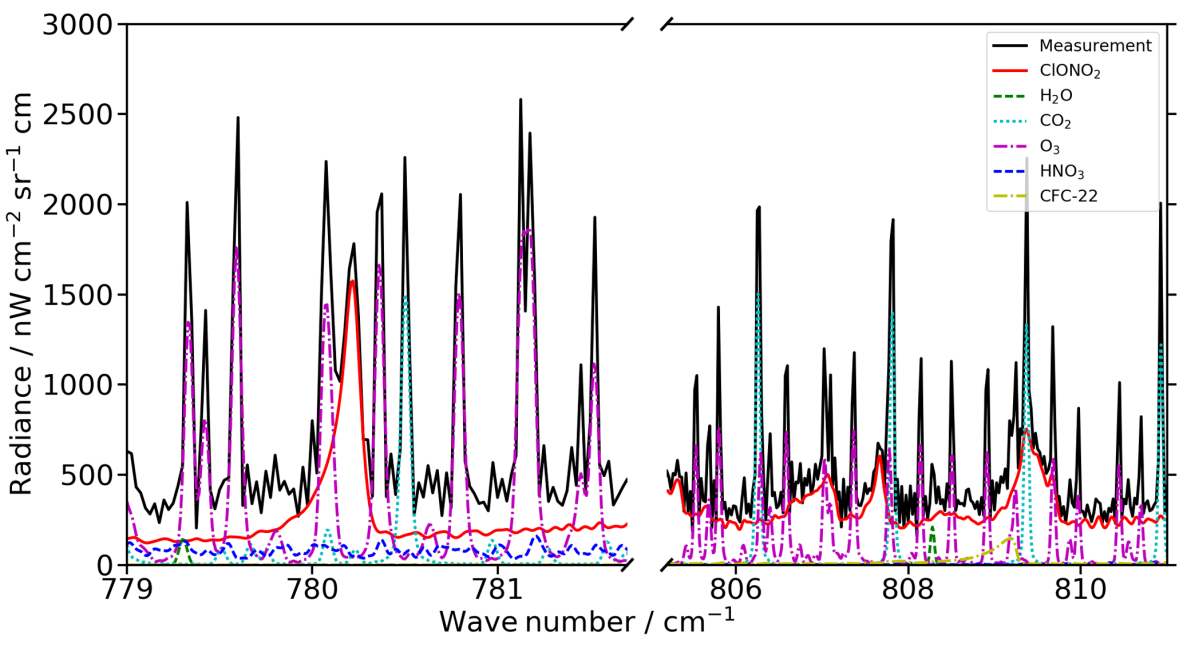

Figure 6. Example of an atmospheric limb emission infrared spectrum measured by MIPAS/Envisat (orbit 05371 ) on 11 March 2003 at 07:36:25 UTC at a tangent altitude of $17.3 \mathrm{~km}$ (black solid line). The contributions of single gases are calculated with the radiative transfer model KOPRA (Karlsruhe Optimized and Precis Radiative Transfer Algorithm; Stiller, 2000) and shown as colored lines $\left(\mathrm{ClONO}_{2}\right.$ is shown as red solid line).

tion Change (NDACC; De Maziére et al., 2018), using high-resolution Fourier transform infrared solar absorption spectroscopy. NDACC infrared stations are situated at $\mathrm{Ny}-$ Ålesund, Spitsbergen; Zugspitze, Germany; Kiruna, Sweden; Izaña, Tenerife; Thule, Greenland; Lauder, New Zealand; Arrival Heights, Antarctica; Jungfraujoch, Switzerland; Rikubetsu, Japan; and Eureka, Canada ${ }^{2}$. Further associated stations which made $\mathrm{ClONO}_{2}$ measurements available are on Kitt Peak (Arizona) and Wollongong (Australia). Details on instrumentation and retrieval as well as references to the original papers are summarized in, e.g., Kohlhepp et al. (2012).

\section{Ground-based lunar absorption spectrometry}

Since solar absorption spectrometry is not possible during polar night, the moon was identified as an alternative source of background radiation. Lunar absorption spectrometry enabled $\mathrm{ClONO}_{2}$ measurements during the entire winter and was applied in Ny-Ålesund, Spitsbergen (Notholt et al., 1993; Notholt, 1994; Notholt et al., 1995).

\section{Airborne solar absorption spectrometry}

The first airborne solar absorption measurements of $\mathrm{ClONO}_{2}$ by high-resolution Fourier transform spectrometry were performed within the framework of the Airborne Antarctic Ozone Experiment (AAOE) (Coffey et al., 1989; Mankin and Coffey, 1989). The Atmospheric Effects of Stratospheric Aircraft (ASHOE/MAESA) ER-2 aircraft mission coincided in time with the Atmospheric Laboratory for Applications and

\footnotetext{
${ }^{2}$ Stations in Toronto, Mauna Loa, Bremen, and Harestua are also equipped to measure $\mathrm{ClONO}_{2}$, but at the time of this writing no related $\mathrm{ClONO}_{2}$ data had been found on the NDACC server.
}

Sciences (ATLAS-3) space mission (Michelsen et al., 1999) (see Sect. 8.1.1).

Airborne $\mathrm{ClONO}_{2}$ solar absorption measurements in the northern polar region in the context of the Airborne Arctic Stratospheric Expedition (AASE) in 1989 were reported by Mankin et al. (1990) and Toon et al. (1992). $\mathrm{ClONO}_{2}$ measurements from the follow-up campaign in 1992 (AASE-2) were published by G. C. Toon et al. (1993).

While, as with ground-based measurements, no profile information but only vertical column densities can be measured, airborne measurements of stratospheric gases are less interfered with by tropospheric constituents. Further, airborne measurements cover a wide range of geolocations. This characteristic was taken advantage of by Toon et al. (1994), who analyzed the latitude distribution of column amounts of trace gases, including $\mathrm{ClONO}_{2}$.

\section{Balloon-borne solar occultation spectrometry}

In contrast to measurement geometries discussed so far, balloon-borne solar occultation provides profile information on $\mathrm{ClONO}_{2}$. The rising or setting sun is observed under varying negative elevation angles. The resulting limb sequence of spectra is inverted to give an altitude profile of the target species.

Murcray et al. (1977) analyzed the spectral region near $780 \mathrm{~cm}^{-1}$ in spectra measured in 1975 from a balloonborne platform for a possible signature of $\mathrm{ClONO}_{2}$ but could only infer upper limits. Spectra measured during subsequent flights were analyzed for a possible signal near $1292 \mathrm{~cm}^{-1}$ without success (Murcray et al., 1978). Analysis of solar occultation spectra measured in 1978 allowed a concentration profile of $\mathrm{ClONO}_{2}$ to be inferred using its signature near 
$1292 \mathrm{~cm}^{-1}$ (Murcray et al., 1979). Further balloon-borne solar occultation measurements were reported by Rinsland et al. (1985), where again the band near $780 \mathrm{~cm}^{-1}$ was analyzed. Solar occultation measurements of $\mathrm{ClONO}_{2}$ in the Arctic were made from stratospheric balloons launched from Kiruna, Sweden (Payan et al., 1998), and from Fairbanks Alaska (Sen et al., 1999; Toon et al., 1999, 2002). With the advent of satellite missions, the focus of balloon-borne measurements shifted somewhat towards validation of spaceborne measurements.

\section{Spaceborne solar occultation spectrometry}

The first spaceborne measurements of $\mathrm{ClONO}_{2}$ were made with the ATMOS instrument from Spacelab 3 in solar occultation (Zander et al., 1986, 1990). Due to the Challenger Space Shuttle accident in January 1986 the ATMOS instrument was not flown until the ATLAS-1 Space Shuttle mission in March 1992, and again $\mathrm{ClONO}_{2}$ was measured (Rinsland et al., 1994). Two further missions followed and provided $\mathrm{ClONO}_{2}$ data: ATLAS-2 in April 1993 (Rinsland et al., 1995) and ATLAS-3 in November 1994 (Rinsland et al., 1996a). A revised analysis of these data, using an improved retrieval algorithm, has been published by Irion et al. (2002).

In August 1996 the Japanese ADEOS satellite was launched into a polar sun-synchronous orbit. Part of the payload was the Improved Limb Atmospheric Spectrometer (ILAS), which, similar as ATMOS, employed the solar occultation measurement geometry. The mission stopped in June 1997. Measurements of $\mathrm{ClONO}_{2}$ in winter/spring 1996/97 were published by Nakajima et al. (2006) and Hayashida et al. (2007). The follow-up instrument, ILASII on the ADEOS-II satellite, was operational from April to October 2003 and also provided $\mathrm{ClONO}_{2}$ data (Griesfeller et al., 2008).

ACE-FTS is a solar occultation instrument on the Canadian SciSat Earth observation satellite, launched in August 2003. $\mathrm{ClONO}_{2}$ measurements have been published by Wolff et al. (2008), Mahieu et al. (2005), Nassar et al. (2006), Dufour et al. (2006), Santee et al. (2008), Jones et al. (2011), Waymark et al. (2013), and Sheese et al. (2016). ACE-FTS is still operational at the time of this writing.

\subsubsection{Emission spectrometry}

\section{Balloon-borne limb emission spectrometry}

The first quantification of $\mathrm{ClONO}_{2}$ in atmospheric limb emission spectra was reported by Brasunas et al. (1988), who used a balloon-borne cryogenic Fourier transform spectrometer SIRIS. Arctic winter and spring profiles were retrieved from spectra measured with the balloon-borne version of the Michelson Interferometer for Passive Atmospheric Sounding (MIPAS-B) by von Clarmann et al. (1993) with an instrument type suggested by Fischer et al. (1983). A pre- liminary $\mathrm{ClONO}_{2}$ retrieval from the same measurements is found in Oelhaf et al. (1994). Müller et al. (1994) reproduced these measurements with a box model. After the loss of the MIPAS-B instrument in March 1992 a new cryogenic limb emission spectrometer was built (MIPAS-B2) and employed in a series of measurement campaigns (Friedl-Vallon et al., 2004). $\mathrm{ClONO}_{2}$ results from these campaign were reported by von Clarmann et al. (1997) and Wetzel et al. (2006, 2008, 2010, 2013). Many of these flights were dedicated to the validation of satellite missions.

\section{Airborne emission spectrometry}

Two versions of airborne MIPAS-type instruments were built, one to be operated in an upward-looking mode from a Transall aircraft (MIPAS-FT) and another for limb emission sounding from the high-flying aircraft M55-Geophysica (MIPAS-STR). $\mathrm{ClONO}_{2}$ results were reported by Blom et al. (1995), Glatthor et al. (1998), and Pfeilsticker et al. (1997) for MIPAS-FT and by Woiwode et al. (2012) for MIPASSTR. The Cryogenic Infrared Spectrometers and Telescopes for the Atmosphere - New Frontiers (CRISTA-NF) instrument, which is a grating spectrometer patterned after its spaceborne namesake, was also used for airborne limb emission measurements of $\mathrm{ClONO}_{2}$ (Ungermann et al., 2012). Measurements with largely improved spatial resolution became possible by limb emission imaging with the Gimballed Limb Observer for Radiance Imaging of the Atmosphere (GLORIA) (Riese et al., 2005; Friedl-Vallon et al., 2006, 2014). For $\mathrm{ClONO}_{2}$, the spectra were analyzed by Johansson et al. (2018).

\section{Spaceborne emission spectrometry}

The first spaceborne limb emission measurements of $\mathrm{ClONO}_{2}$ were made with CLAES on UARS Roche et al. (1993, 1994). Riese et al. (1997, 1999) and Spang et al. (2001) reported $\mathrm{ClONO}_{2}$ measurements with the CRISTA instrument, which was operated from the Shuttle Pallet Satellite (SPAS) during Space Shuttle missions in 1994 and 1997. The most extended global $\mathrm{ClONO}_{2}$ data set, which also covers polar night distributions, was inferred from MIPASEnvisat measurements (Höpfner et al., 2004, 2007). After an instrument failure in 2004 MIPAS resumed operation at reduced spectral resolution, which still allowed retrieval of $\mathrm{ClONO}_{2}$ (von Clarmann et al., 2009). MIPAS data cover the time period from August 2002 to April 2012, with a major data gap in 2004 and periods of particularly sparse measurements in 2005 and 2006. An improved data version based on revised calibration was presented by von Clarmann et al. (2013). While initially not part of the original MIPAS ESA data product, $\mathrm{ClONO}_{2}$ was included later (Raspollini et al., 2013). Further MIPAS $\mathrm{ClONO}_{2}$ retrievals were provided, e.g., by Arnone et al. (2012) 

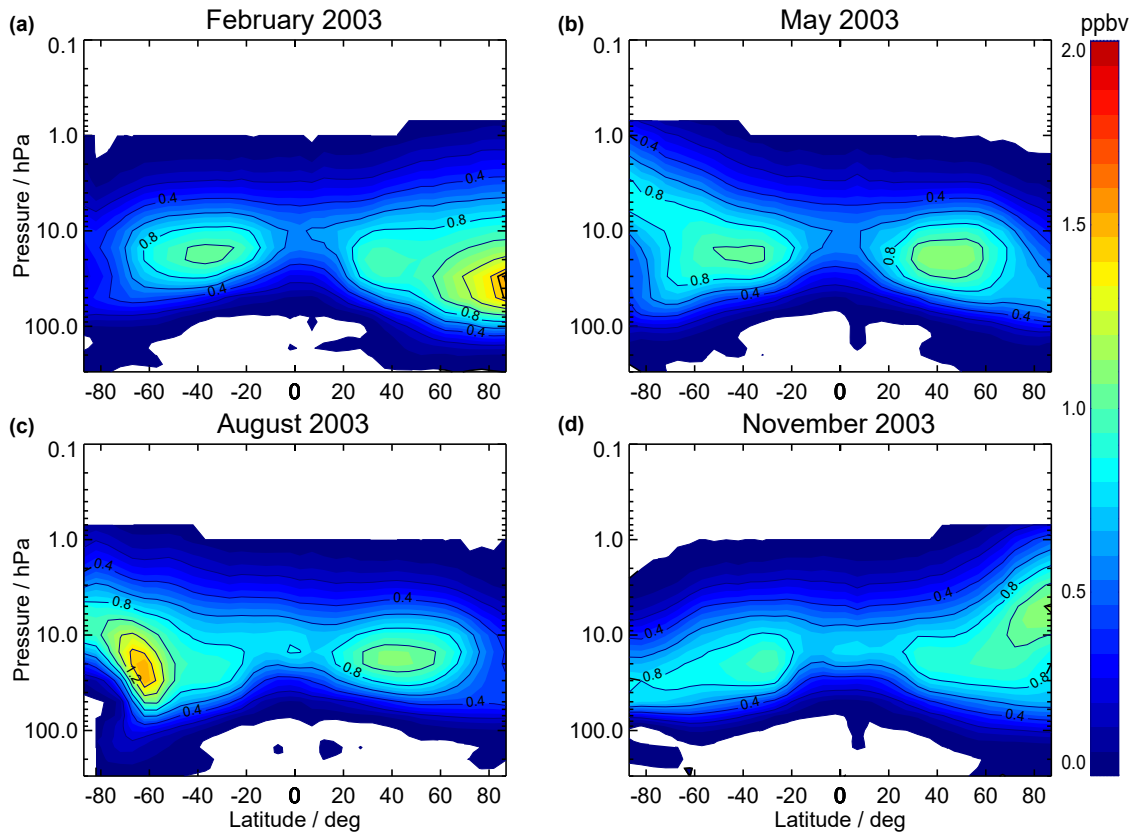

Figure 7. $\mathrm{ClONO}_{2}$ latitude-pressure cross sections for February, May, August, and November 2003 as measured with MIPAS.

\subsection{In situ measurements}

\subsubsection{Fluorescence measurements}

The first airborne in situ measurements of $\mathrm{ClONO}_{2}$ were made with a thermal dissociation/resonance fluorescence measurement technique on the NASA ER-2 aircraft during the POLARIS (Polar Ozone Loss in the Arctic Region In Summer) mission from April to September 1997 (Stimpfle et al., 1999; Bonne et al., 2000). This measurement technique uses the fact that $\mathrm{ClONO}_{2}$ dissociates into $\mathrm{ClO}$ and $\mathrm{NO}_{2}$ by heating the gas. The products of this dissociation are then detected separately. The $\mathrm{ClO}$ molecule reacts with added $\mathrm{NO}$ to atomic $\mathrm{Cl}$, which then are detected by resonance fluorescence in the ultraviolet. $\mathrm{ClO}$ that is present in the atmosphere is measured separately in order to subtract the influence of ambient $\mathrm{ClO}$ on the measurement of $\mathrm{ClO}$ dissociated from $\mathrm{ClONO}_{2}$. The $\mathrm{NO}_{2}$ molecule from dissociation of $\mathrm{ClONO}_{2}$ could be measured by laser-induced resonance fluorescence, but in practice this measurement was not possible due to the added $\mathrm{NO}$ for dissociation of $\mathrm{ClO}$. The thermal dissociation/resonance fluorescence technique provides measurements of $\mathrm{ClONO}_{2}$ with an accuracy of $\pm 20 \%$, a detection limit of $10 \mathrm{pptv}$, and a temporal resolution of $35 \mathrm{~s}$. A similar technique has been applied by von Hobe et al. (2003) and Stroh et al. (2011) with the HALOX instrument.

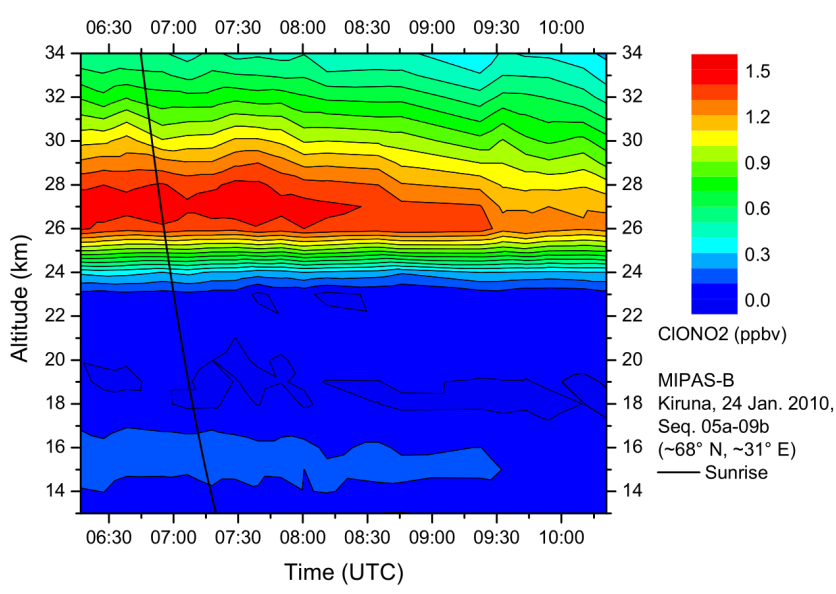

Figure 8. $\mathrm{ClONO}_{2}$ volume mixing ratios measured with MIPASB during sunrise on 24 January 2010 above northern Scandinavia within the polar vortex. Figure taken from Wetzel et al. (2012, their Fig. 8) under CC Attribution 3.0 License.

\subsubsection{Mass spectroscopy}

A more recent technology for in situ detection of $\mathrm{ClONO}_{2}$ is chemical ionization mass spectrometry (CIMS). This is a measurement technique that has been utilized by airborne instruments for in situ measurements of $\mathrm{ClONO}_{2}$. Mass spectrometry sorts chemical ions according to their mass-tocharge ratio, utilizing magnetic fields for separating these ions. For ionization of $\mathrm{ClONO}_{2}$, a reaction with $\mathrm{SF}_{5}^{-}$gives 


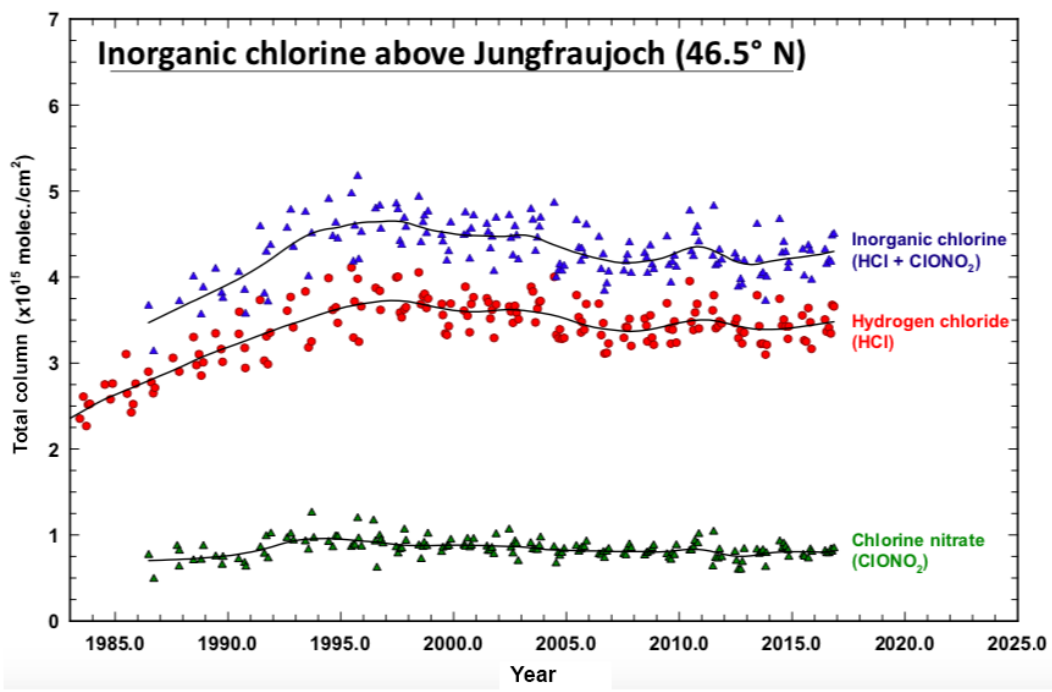

Figure 9. Multidecadal time series of column amounts above Jungfraujoch of $\mathrm{ClONO}_{2}$ and $\mathrm{HCl}$, as well as the sum of both, which is a proxy of total inorganic chlorine. Symbols represent monthly means. To avoid masking of trends by polar winter dynamics, only the months June to November were considered. The continuous lines are non-parametric least squares fits. A decrease since 1996/97 and correlations between the column amounts of $\mathrm{ClONO}_{2}$ and those of $\mathrm{HCl}$ are visible. Figure by Emmanuel Mahieu et al., Univ. Liège, published in De Maziére et al. (2018), used under CC Attribution 3.0 license.

$\mathrm{F}^{-} \mathrm{ClONO}_{2}$, which is then detected. For accurate measurements calibrations with reference gases are necessary.

The first CIMS instrument was used on the NASA WB57F aircraft during the CRYSTAL-FACE mission from Key West, FL, in 2002 (Marcy et al., 2005). CIMS $\mathrm{ClONO}_{2}$ measurements were calibrated using laboratory measurements after the campaign with reference gases. A correlation of $\mathrm{ClONO}_{2}$ with simultaneously measured $\mathrm{HNO}_{3}$ was applied to use in-flight calibrations of $\mathrm{HNO}_{3}$ also for $\mathrm{ClONO}_{2}$ measurements. Uncertainties of the ground-based calibration lead to a relative error of $\pm 50 \%$ of measured $\mathrm{ClONO}_{2}$.

The AIMS (AIrborne Mass Spectrometer) instrument was deployed on the German High Altitude and Long Range Research Aircraft (HALO) during the TACTS/ESMVal campaign in 2012 (Jurkat et al., 2016, 2017). Again, calibration measurements are performed on the ground using reference gases, and a correlation of $\mathrm{ClONO}_{2}$ with $\mathrm{HCl}$ is applied to use in-flight calibrations for $\mathrm{HCl}$. AIMS measures $\mathrm{ClONO}_{2}$ at a temporal resolution of $1.7 \mathrm{~s}$ with a detection limit of 20 pptv, $\pm 15 \%$ precision, and $\pm 20 \%$ accuracy.

\section{The climatology of $\mathrm{ClONO}_{2}$}

\subsection{Zonal mean distributions and annual cycle}

Largest mixing ratios of $\mathrm{ClONO}_{2}$ are found at altitudes of around 30 to $10 \mathrm{hPa}$ (roughly 20-30 km) (Fig. 7). Minimal concentrations are found in the tropics. In late local winter maximal mixing ratios are found in polar regions, associated with chlorine deactivation (Figs. 7a and c, and 3). Under these conditions, mixing ratios can exceed 2 ppbv. As first found by Toon et al. (1989), largest concentrations are not found directly above the pole but in a collar at the edge of the polar vortex. An example of such a $\mathrm{ClONO}_{2}$ collar as measured by MIPAS is shown in Fig. 4. In spring, summer, and autumn the largest mixing ratios are found at midlatitudes.

Climatologies of $\mathrm{ClONO}_{2}$ generated from measurements by multiple spaceborne limb sounders have been compiled by Hegglin and Tegtmeier (2017) and are accessible via http://www.sparc-climate.org/data-centre/data-access/ sparc-data-initiative/ (last access: 19 October 2018).

\subsection{Diurnal Cycle}

The diurnal variation of $\mathrm{ClONO}_{2}$ in the Arctic winter stratosphere is driven by the availability of sunlight. Wetzel et al. (2012) measured the $\mathrm{ClONO}_{2}$ volume mixing ratio with MIPAS-B2 within the polar vortex above northern Scandinavia during sunrise on 24 January 2010 (see Fig. 8). The maximum volume mixing ratio for $\mathrm{ClONO}_{2}$ was $1.5 \mathrm{ppbv}$, observed at an altitude of $27 \mathrm{~km} 1 \mathrm{~h}$ before sunrise. During the time period of $1-2 \mathrm{~h}$ after sunrise, $\mathrm{ClONO}_{2}$ levels decreased to $1.3 \mathrm{ppbv}$. They explained this decrease after sunrise with the start of photolysis of the $\mathrm{ClONO}_{2}$ molecule (see Sect. 5.1) and the photolysis of the $\mathrm{NO}_{2}$ molecule, which is needed for the source reaction of $\mathrm{ClONO}_{2}$ (see Sect. 4). The diurnal cycle of $\mathrm{ClONO}_{2}$ is often discussed within the context of the diurnal cycle of $\mathrm{ClO}$ in which $\mathrm{ClONO}_{2}$ acts as a reservoir species. The first theoretical calculations for the diurnal cycle of $\mathrm{ClONO}_{2}$ were done by Ko and Sze (1984) in 
Table 5. Sources of $\mathrm{ClONO}_{2}$ data.

\begin{tabular}{lll}
\hline Instrument & Institution & Web address (last access: 19 October 2018) \\
\hline Ground-based FTIR & NDACC & http://www.ndsc.ncep.noaa.gov/cgi-bin/pi/query_data/query_data.pl \\
ACE-FTS & Univ. Waterloo & http://www.ace.uwaterloo.ca/data.php \\
ATMOS & NASA JPL & https://remus.jpl.nasa.gov/atmos/atftp.html \\
CLAES & NASA & https://disc.gsfc.nasa.gov/datasets/UARCL3AT_V009/summary?keywords=CLAES\&page=1 \\
CRISTA-NF & FZJ/BUW & https://www.fp7-reconcile.eu/reconciledata \\
GLORIA & KIT/FZJ & https://doi.org/10.5445/IR/1000086506 \\
ILAS & NIES & http://warp.da.ndl.go.jp/info:ndljp/pid/11066775/db.cger.nies.go.jp/ilas/data2/DataDistribution.html \\
ILAS-II & NIES & http://warp.da.ndl.go.jp/info:ndljp/pid/11066775/db.cger.nies.go.jp/ilas2/en/dist/genelal/DataDistribution.html \\
MIPAS & KIT/IMK & $\mathrm{http://www.imk-asf.kit.edu/english/308.php}$ \\
MIPAS & ESA & https://earth.esa.int/web/guest/missions/esa-operational-eo-missions/envisat/instruments/mipas \\
MIPAS & Univ. Oxford & $\mathrm{http}: / /$ eodg.atm.ox.ac.uk/MIPAS/L2OXF/ \\
MIPAS-STR & KIT/IMK & $\mathrm{https://www.fp7-reconcile.eu/reconciledata}$ \\
MK-IV & NASA JPL & $\mathrm{https://mark4sun.jpl.nasa.gov/ground.html}$ \\
\hline
\end{tabular}

the context of measurements of the diurnal cycle of $\mathrm{ClO}$ by Solomon et al. (1984).

\section{Trends of $\mathrm{ClONO}_{2}$}

As with $\mathrm{HCl}$, one of the main scientific questions is how the time series reflect the decrease of CFCs after the Montreal Protocol. Rinsland et al. (2010) found that $\mathrm{ClONO}_{2}$ stopped increasing. Negative trends have actually been determined (Fig. 9), and the decrease of $\mathrm{ClONO}_{2}$ was observed to be stronger than that of $\mathrm{HCl}$. This difference was observed to be latitude dependent (Kohlhepp et al., 2012).

\section{$11 \mathrm{ClONO}_{2}$ data sets}

Numerous $\mathrm{ClONO}_{2}$ observational data sets are available via the internet. Some relevant addresses are compiled in Table 5. $\mathrm{ClONO}_{2}$ data of missions not listed may be available via the respective principal investigators.

\section{Conclusion and outlook}

Research during the last decades has helped very much to mature our knowledge about $\mathrm{ClONO}_{2}$, in particular in the context of polar stratospheric ozone depletion. The most relevant future science questions presumably regard (a) the future development of $\mathrm{ClONO}_{2}$ concentrations in a changing climate and (b) its role in chlorine activation on surfaces other than polar stratospheric clouds, particularly in the upper troposphere and lowermost stratosphere.

Data availability. No original data sets were used in this article.

Author contributions. TvC drafted major parts of Sects. 1-6 and 8.1. SJ drafted Sects. 7 and 8.2 and provided Table 4. Sections 9-
11 were fully co-authored. Both authors contributed equally to the refinement of the draft version.

Competing interests. Thomas von Clarmann is co-editor of $A C P$ and executive editor of the Encyclopedia of Geosciences but was not involved in the evaluation of the paper.

Acknowledgements. The authors thank Thomas Blumenstock, Michael Höpfner, Frederick W. Irion, Rolf Müller, Piera Raspollini, Rolf Sander, Gabriele Stiller, and Mingjin Tang for helpful comments. The reviews by Chris Boone and an anonymous reviewer as well as the editor comments by Martyn Chipperfield have helped to improve the paper.

The article processing charges for this open-access publication were covered by a Research Centre of the Helmholtz Association.

Edited by: Martyn Chipperfield

Reviewed by: Chris Boone and one anonymous referee

\section{References}

Abbatt, J. P. D. and Molina, M. J.: Heterogeneous interactions of nitryl hypochlorite and hydrogen chloride on nitric acid trihydrate at $202 \mathrm{~K}$, J. Phys. Chem., 96, 7674-7679, https://doi.org/10.1021/j100198a036, 1992.

Adrian, G. P., Baumann, M., Blumenstock, T., Fischer, H., Friedle, A., Gerhardt, L., Maucher, G., Oelhaf, H., Scheuerpflug, W., Thomas, P., Trieschmann, O., and Wegner, A.: First Results of ground-based FTIR measurements of atmospheric trace gases in north Sweden and Greenland during EASOE, Geophys. Res. Lett., 21, 1343-1346, 1994.

Allanic, A., Oppliger, R., van den Bergh, H., and Rossi, M. J.: The Heterogeneous Kinetics of the Reactions $\mathrm{ClONO}_{2}+\mathrm{HX} /$ ice $(\mathrm{X}=\mathrm{Br}, \mathrm{I}), \mathrm{BrONO}_{2}+\mathrm{HI} /$ ice and the Reactivity of the Interhalogens $\mathrm{BrCl}$, ICI and $\mathrm{IBr}$ with $\mathrm{HX} /$ ice $(\mathrm{X}=\mathrm{Cl}, \mathrm{Br}, \mathrm{I})$ in the 
Temperature Range 180 to 205 K, Z. Phys. Chem., 214, 14791500, https://doi.org/10.1524/zpch.2000.214.11.1479, 2000.

Anderson, J. G., Brune, W. H., Lloyd, S. A., Toohey, D. W., Sander, S. P., Starr, W. L., Loewenstein, M., and Podolske, J. R.: Kinetics of $\mathrm{O}_{3}$ Destruction by $\mathrm{ClO}$ and $\mathrm{BrO}$ Within the Antarctic Vortex: An Analysis based on in Situ ER-2 Data, J. Geophys. Res., 94, 11480-11520, 1989.

Anderson, J. G., Toohey, D. W., and Brune, W. H.: Free radicals within the Antarctic vortex: The role of CFCs in Antarctic ozone loss, Science, 251, 39-46, https://doi.org/10.1126/science.251.4989.39, 1991.

Arnone, E., Castelli, E., Papandrea, E., Carlotti, M., and Dinelli, B. M.: Extreme ozone depletion in the 2010-2011 Arctic winter stratosphere as observed by MIPAS/ENVISAT using a 2D tomographic approach, Atmos. Chem. Phys., 12, 9149-9165, https://doi.org/10.5194/acp-12-9149-2012, 2012.

Arrhenius, S.: Über die Reaktionsgeschwindigkeit bei der Inversion von Rohrzucker durch Säuren, Z. Phys. Chem., 4U, 226-248, https://doi.org/10.1515/zpch-1889-0416, 1889.

Avallone, L. M., Toohey, D. W., Proffitt, M. H., Margitan, J. J., Chan, K. R., and Anderson, J. G.: In situ measurements of $\mathrm{ClO}$ at mid-latitudes: Is there an effect from Mt. Pinatubo?, Geophys. Res. Lett., 20, 2519-2522, 1993.

Ball, S. M., Fried, A., Henry, B. E., and Mozurkewich, M.: The hydrolysis of $\mathrm{ClONO}_{2}$ on sub-micron liquid sulfuric acid aerosol, Geophys. Res. Lett., 25, 3339-3342, 1998.

Ballard, J., Johnston, W. B., Gunson, M. R., and Wassell, P. T.: Absolute Absorption Coefficients of $\mathrm{ClONO}_{2}$ Infrared Bands at Stratospheric Temperatures, J. Geophys. Res., 93, 1659-1665, 1988.

Barone, S. B., Zondlo, M. A., and Tolbert, M. A.: A Kinetic and Product Study of the Hydrolysis of $\mathrm{ClONO}_{2}$ on Type Ia Polar Stratospheric Cloud Materials at 185 K, J. Phys. Chem. A, 101, 8643-8652, 1997.

Barrett, J. W., Solomon, P. M., de Zafra, R. L., Jaramillo, M., Emmons, L., and Parrish, A.: Formation of the Antarctic ozone hole by the $\mathrm{ClO}$ dimer mechanism, Nature, 336, 455-458, 1988.

Batchelor, R. L., Kolonjari, F., Lindenmaier, R., Mittermeier, R. L., Daffer, W., Fast, H., Manney, G., Strong, K., and Walker, K. A.: Four Fourier transform spectrometers and the Arctic polar vortex: instrument intercomparison and ACE-FTS validation at Eureka during the IPY springs of 2007 and 2008, Atmos. Meas. Tech., 3, 51-66, https://doi.org/10.5194/amt-3-51-2010, 2010.

Bell, W., Martin, N. G., Gardiner, T. D., Swann, N. R., Woods, P. T., Fogal, P. F., and Waters, J. W.: Column measurements of stratospheric trace species over Åre, Sweden, in the winter 1991-1992, Geophys. Res. Lett., 21, 1347-1350, 1994.

Bell, W., Paton-Walsh, C., Gardiner, T. D., Woods, P. T., Donohoe, L., Gould, A., Secker, D., Naughten, S., Swann, N. R., Martin, N. A., Page, L. E., Chipperfield, M. P., Lee, A. M., and Pullen, S.: Ground-based FTIR Measurements of Stratospheric Trace Species from Aberdeen During Winter and Spring 1993/94 and 1994/95 and Comparison with a 3D Model, J. Atmos. Chem., 30, 119-130, 1998a.

Bell, W., Paton-Walsh, C., Woods, P. T., Gardiner, T. D., Chipperfield, M. P., and Lee, A. M.: Ground-based FTIR Measurements with High Temporal Resolution, J. Atmos. Chem., 30, 131-140, $1998 b$.
Berko, H. N., McCaslin, P. C., and Finlayson-Pitts, B. J.: Formation of gas-phase bromine compounds by reaction of solid $\mathrm{NaBr}$ with gaseous $\mathrm{ClONO}_{2}, \mathrm{Cl}_{2}$ and $\mathrm{BrCl}$ at $298 \mathrm{~K}$, J. Phys. Chem., 95, 6951-6958, https://doi.org/10.1021/j100171a041, 1991.

Birk, M. and Wagner, G.: A New Spectroscopic Database for Chlorine Nitrate, in: Proceedings of the 6th Biennial HITRAN Database Conference, 19-21 June 2000, Cambridge, MA, USA, 2000.

Birks, J. W., Shoemaker, B., Leck, T. J., Borders, R. A., and Hart, L. J.: Studies of reactions of importance in the stratosphere. II. Reactions involving chlorine nitrate and chlorine dioxide., J. Chem. Phys., 66, 4591-4599, https://doi.org/10.1063/1.433716, 1977.

Blom, C., Fischer, H., Glatthor, N., Gulde, T., Höpfner, M., and Piesch, C.: Spatial and temporal variability of $\mathrm{ClONO}_{2}, \mathrm{HNO}_{3}$ and $\mathrm{O}_{3}$ in the Arctic winter of $1992 / 93$ as obtained by airborne infrared emission spectroscopy, J. Geophys. Res., 100, 91019114, 1995.

Blumenstock, T., Fischer, H., Friedle, A., Hase, F., and Thomas, P.: Column Amounts of $\mathrm{ClONO}_{2}, \mathrm{HCl}, \mathrm{HNO}_{3}$, and $\mathrm{HF}$ from Ground-Based FTIR Measurements Made Near Kiruna, Sweden in Late Winter 1994, J. Atmos. Chem., 26, 311-321, 1997.

Blumenstock, T., Fischer, H., Friedle, A., Stiller, G. P., and Thomas, P.: Column amounts of $\mathrm{HCl}, \mathrm{ClONO}_{2}$ and $\mathrm{HF}$ measured by ground-based FTIR spectroscopy near Kiruna (S) during winter since 1990, in: Atmospheric Ozone, Proceedings of the XVIII Quadrennial Ozone Symposium, 12-21 September 1996, L'Aquila, Italy, edited by: Bojkov, R. D. and Visconti, G., vol. 1, 469-472, International Ozone Comission, 1998.

Blumenstock, T., Hase, F., Fischer, H., Stiller, G. P., Meier, A., Steen, A., Yashkov, D., and Kondo, Y.: Ground Based FTIR Measurements of $\mathrm{O}_{3}, \mathrm{HF}, \mathrm{HCl}, \mathrm{ClONO}_{2}, \mathrm{NO}_{2}, \mathrm{NO}$, and $\mathrm{HNO}_{3}$ at Kiruna (Sweden) since winter 1994, in: Proceedings of the Quadrennial Ozone Symposium, 3-8 July 2000, Sapporo, Japan, NASDA, 145-146, 2000.

Blumenstock, T., Kopp, G., Hase, F., Hochschild, G., Mikuteit, S., Raffalski, U., and Ruhnke, R.: Observation of unusual chlorine activation by ground-based infrared and microwave spectroscopy in the late Arctic winter 2000/01, Atmos. Chem. Phys., 6, 897905, https://doi.org/10.5194/acp-6-897-2006, 2006.

Bonne, G. P., Stimpfle, R. M., Cohen, R. C., Voss, P. B., Perkins, K. K., Anderson, J. G., Salawitch, R. J., Elkins, J. W., Dutton, G. S., Jucks, K. W., and Toon, G. C.: An examination of the inorganic chlorine budget in the lower stratosphere, J. Geophys. Res., 105, 1957-1971, 2000.

Borrmann, S., Solomon, S., Dye, J. E., Baumgardner, D., Kelly, K. K., and Chan, K. R.: Heterogeneous reactions on stratospheric background aerosols, volcanic sulfuric acid droplets, and type I polar stratospheric clouds: Effects of temperature fluctuations and differences in particle phase, J. Geophys. Res., 102, 36393648, 1997.

Brasseur, G.: Volcanic aerosols implicated, Nature, 359, 275-276, 1992.

Brasseur, G. and Solomon, S.: Aeronomy of the Middle Atmosphere-Chemistry and Physics of the Stratosphere and Mesosphere, Atmospheric and Oceanographic Sciences Library 32, third edn., Springer, Dordrecht, the Netherlands, 2005.

Brasunas, J. C., Kunde, V. G., Hanel, R. A., Walser, D., Herath, L. W., Buijs, H. L., Bérubé, J. N., and McKinnon, J.: Balloon- 
borne cryogenic spectrometer for measurement of lower stratospheric trace constituents, in: Proc. SPIE, vol. 619, 80-88, SPIE, Bellingham, WA, USA, 1986.

Brasunas, J. C., Kunde, V. G., and Herath, L. W.: Cryogenic Fourier spectrometer for measuring trace species in the lower stratosphere, Appl. Optics, 27, 4964-4976, 1988.

Browell, E. V., Butler, C. F., Fenn, M. A., Grant, W. B., Ismail, S., Schoeberl, M. R., Toon, O. B., Loewenstein, M., and Podolske, J. R.: Ozone and aerosol changes during the 1991-1992 Airborne Arctic Stratospheric Expedition, Science, 261, 1155-1158, 1993.

Brune, W. H., Anderson, J. G., and Chan, K. R.: In situ observations of $\mathrm{ClO}$ in the Antarctic: ER-2 aircraft results from $54^{\circ} \mathrm{S}$ to $72^{\circ} \mathrm{S}$ latitude, J. Geophys. Res., 94, 16649-16663, 1989.

Burkholder, J. B., Talukdar, R. K., and Ravishankara, A. R.: Temperature dependence of the $\mathrm{ClONO}_{2} \mathrm{UV}$ absorption spectrum, Geophys. Res. Lett., 21, 585-588, https://doi.org/10.1029/93GL03303, 1994.

Burkholder, J. B., Abbat, J. P. D., Huie, R. E., Kurylo, M. J., Wilmouth, D. M., Sander, S. P., Barker, J. R., Kolb, C. E., Orkin, V. L., and Wine, P. H.: Chemical Kinetics and Photochemical Data for Use in Atmospheric Studies, Tech. Rep. JPL Publication 15-10, NASA, JPL, California Institute of Technology, Pasadena, CA, USA, 2015.

Butler, R. A. H., Petkie, D. T., Helminger, P., De Lucia, F. C., and Kisiel, Z.: The rotational spectrum of chlorine nitrate $\left(\mathrm{ClONO}_{2}\right)$ : The $v_{5} / v_{6} v_{9}$ dyad, J. Mol. Spectrosc., 243, 1-9, https://doi.org/10.1016/j.jms.2007.02.023, 2007.

Carslaw, K. S. and Peter, T.: Uncertainties in reactive uptake coefficients for solid stratospheric particles-1. Surface chemistry, Geophys. Res. Lett., 24, 1743-1746, https://doi.org/10.1029/97GL01683, 1997.

Chipperfield, M. P. and Pyle, J. A.: Model sensitivity studies of Arctic ozone depletion, J. Geophys. Res., 103, 28389-28403, 1998.

Chipperfield, M. P., Lutman, E. R., Kettleborough, J. A., Pyle, J. A., and Roche, A. E.: Model studies of chlorine deactivation and formation of $\mathrm{ClONO}_{2}$ collar in the Arctic polar vortex, J. Geophys. Res., 102, 1467-1478, 1997.

Chu, L. T., Leu, M. T., and Keyser, L. F.: Uptake of hydrogen chloride in water ice and nitric acid ice films, J. Phys. Chem., 97, 7779-7785, https://doi.org/10.1021/j100131a057, 1993.

Chubachi, S.: A Special Ozone Observation at Syowa Station, Antarctica from February 1982 to January 1983, in: Atmospheric Ozone, Proceedings of the Quadrennial Ozone Symposium, 37 September 1984, Halkidiki, Greek, edited by: Zerefos, C. S. and Ghazi, A., 285-289, 1984a.

Chubachi, S.: Preliminary result of ozone observations at Syowa Station from February 1982 to January 1983, in: Memoirs of National Institute of Polar Research Special Issue No. 34, Proceedings of the Sixth Symposium on Polar Meteorology and Glaciology, December 1984, Tokyo, Japan, 13-19, 1984b.

Coffey, M. T., Mankin, W. G., and Goldman, A.: Airborne Measurements of Stratospheric Constituents Over Antarctica in the Austral Spring, 1987. 2. Halogen and Nitrogen Trace Gases, J. Geophys. Res., 94, 16597-16613, 1989.

Cox, R. A. and Hayman, G. D.: The stability and photochemistry of dimers of the $\mathrm{ClO}$ radical and implications for Antarctic ozone depletion, Nature, 332, 796-800, https://doi.org/10.1038/332796a0, 1988.
Cox, R. A., MacKenzie, A. R., Müller, R. H., Peter, T., and Crutzen, P. J.: Activation of stratospheric chlorine by reactions in liquid sulphuric acid, Geophys. Res. Lett., 21, 1439-1442, 1994.

Crutzen, P.: The influence of nitrogen oxides on the atmospheric ozone content, Q. J. Roy. Meteor. Soc., 96, 320-325, 1970.

Damiani, A., Funke, B., Marsh, D. R., López-Puertas, M., Santee, M. L., Froidevaux, L., Wang, S., Jackman, C. H., von Clarmann, T., Gardini, A., Cordero, R. R., and Storini, M.: Impact of January 2005 solar proton events on chlorine species, Atmos. Chem. Phys., 12, 4159-4179, https://doi.org/10.5194/acp12-4159-2012, 2012.

Deiber, G., George, Ch., Le Calvé, S., Schweitzer, F., and Mirabel, Ph.: Uptake study of $\mathrm{ClONO}_{2}$ and $\mathrm{BrONO}_{2}$ by Halide containing droplets, Atmos. Chem. Phys., 4, 1291-1299, https://doi.org/10.5194/acp-4-1291-2004, 2004.

De Mazière, M., Thompson, A. M., Kurylo, M. J., Wild, J. D., Bernhard, G., Blumenstock, T., Braathen, G. O., Hannigan, J. W., Lambert, J.-C., Leblanc, T., McGee, T. J., Nedoluha, G., Petropavlovskikh, I., Seckmeyer, G., Simon, P. C., Steinbrecht, W., and Strahan, S. E.: The Network for the Detection of Atmospheric Composition Change (NDACC): history, status and perspectives, Atmos. Chem. Phys., 18, 4935-4964, https://doi.org/10.5194/acp-18-4935-2018, 2018.

Deshler, T., Adriani, A., Hofmann, D. J., and Gobbi, G. P.: Evidence for denitrification in the 1990 Antarctic spring stratosphere: II. Lidar and aerosol measurements, Geophys. Res. Lett., 18, 1999-2002, 1991.

Dessler, A. E., Stimpfle, R. M., Daube, B. C., Salawitch, R. J., Weinstock, E. M., Judah, D. M., Burley, J. D., Munger, J. W., Wofsy, S. C., Anderson, J. G., McCormick, M. P., and Chu, W. P.: Balloon-borne measurements of $\mathrm{ClO}, \mathrm{NO}$, and $\mathrm{O}_{3}$ in a volcanic cloud: An analysis of heterogeneous chemistry between 20 and 30 km, Geophys. Res. Lett., 20, 2527-2530, 1993.

de Zafra, R. L., Jaramillo, M., Parrish, A., Solomon, P., Connor, B., and Barrett, J.: High concentrations of chlorine monoxide at low altitudes in the Antarctic spring stratosphere: diurnal variation, Nature, 328, 408-411, 1987.

Douglass, A. R., Schoeberl, M. R., Stolarski, R. S., Waters, J. W., Russell III, J. M., Roche, A. E., and Massie, S. T.: Interhemispheric differences in springtime production of $\mathrm{HCl}$ and $\mathrm{ClONO}_{2}$ in the polar vortices, J. Geophys. Res., 100, 13,967-13,978, 1995.

Drdla, K. and Müller, R.: Temperature thresholds for chlorine activation and ozone loss in the polar stratosphere, Ann. Geophys., 30, 1055-1073, https://doi.org/10.5194/angeo-30-10552012, 2012.

Dufour, G., Nassar, R., Boone, C. D., Skelton, R., Walker, K. A., Bernath, P. F., Rinsland, C. P., Semeniuk, K., Jin, J. J., McConnell, J. C., and Manney, G. L.: Partitioning between the inorganic chlorine reservoirs $\mathrm{HCl}$ and $\mathrm{ClONO}_{2}$ during the Arctic winter 2005 from the ACE-FTS, Atmos. Chem. Phys., 6, 23552366, https://doi.org/10.5194/acp-6-2355-2006, 2006.

Fahey, D. W., Kelly, K. K., Kawa, S. R., Tuck, A. F., Loewenstein, M., Chan, K. R., and Heidt, L. E.: Observations of denitrification and dehydration in the winter polar stratospheres, Nature, 344, 321-324, 1990.

Fahey, D. W., Kawa, S. R., Woodbridge, E. L., Tin, P., Wilson, J. C., Jonsson, H. H., Dye, J. E., Baumgardner, D., Borrmann, S., Toohey, D. W., Avallone, L. M., Proffitt, M. H., Margitan, 
J., Loewenstein, M., Podolske, J. R., Salawitch, R. J., Wofsy, S. C., Ko, M. K. W., Anderson, A. E., Schoeberl, M. R., and Chan, K. R.: In situ measurements constaining the role of sulphate aerosols in mid-latitude ozone depletion, Nature, 363, 509514, 1993.

Farman, J. C., Gardiner, B. G., and Shanklin, J. D.: Large losses of total ozone in Antarctica reveal seasonal $\mathrm{ClO}_{x} / \mathrm{NO}_{x}$ interaction, Nature, 315, 207-210, 1985.

Farmer, C. B., Toon, G. C., Schaper, P. W., Blavier, J.-F., and Lowes, L. L.: Stratospheric trace gases in the spring 1986 Arctic atmosphere, Nature, 329, 126-130, 1987.

Finlayson-Pitts, B. J., Ezell, M. J., and J. N. Pitts, J.: Formation of chemically active chlorine compounds by reactions of atmospheric $\mathrm{NaCl}$ particles with gaseous $\mathrm{N}_{2} \mathrm{O}_{5}$ and $\mathrm{ClONO}_{2}$, Nature, 337, 241-244, https://doi.org/10.1038/337241A0, 1989.

Fischer, H., Fergg, F., Oelhaf, H., Rabus, D., Völker, W., and Burkert, P.: Simultaneous Detection of Trace Constituents in the Middle Atmosphere with a Small He-Cooled, High Resolution Michelson Interferometer (MIPAS), Contr. Atmos. Phys., 56, 260-275, 1983.

Friedl-Vallon, F., Maucher, G., Kleinert, A., Lengel, A., Keim, C., Oelhaf, H., Fischer, H., Seefeldner, M., and Trieschmann, O.: Design and characterisation of the ballon-borne Michelson Interferometer for Passive Atmospheric Sounding (MIPAS-B2), Appl. Optics, 43, 3335-3355, 2004

Friedl-Vallon, F., Riese, M., Maucher, F., Lengel, A., Hase, F., Preusse, P., and Spang, R.: Instrument concept and preliminary performance analysis of GLORIA, Adv. Space Res., 37, $2287-$ 2291, https://doi.org/10.1016/j.asr.2005.07.075, 2006.

Friedl-Vallon, F., Gulde, T., Hase, F., Kleinert, A., Kulessa, T., Maucher, G., Neubert, T., Olschewski, F., Piesch, C., Preusse, P., Rongen, H., Sartorius, C., Schneider, H., Schönfeld, A., Tan, V., Bayer, N., Blank, J., Dapp, R., Ebersoldt, A., Fischer, H., Graf, F., Guggenmoser, T., Höpfner, M., Kaufmann, M., Kretschmer, E., Latzko, T., Nordmeyer, H., Oelhaf, H., Orphal, J., Riese, M., Schardt, G., Schillings, J., Sha, M. K., Suminska-Ebersoldt, O., and Ungermann, J.: Instrument concept of the imaging Fourier transform spectrometer GLORIA, Atmos. Meas. Tech., 7, 35653577, https://doi.org/10.5194/amt-7-3565-2014, 2014.

Funke, B., Baumgaertner, A., Calisto, M., Egorova, T., Jackman, C. H., Kieser, J., Krivolutsky, A., López-Puertas, M., Marsh, D. R., Reddmann, T., Rozanov, E., Salmi, S.-M., Sinnhuber, M., Stiller, G. P., Verronen, P. T., Versick, S., von Clarmann, T., Vyushkova, T. Y., Wieters, N., and Wissing, J. M.: Composition changes after the "Halloween" solar proton event: the High Energy Particle Precipitation in the Atmosphere (HEPPA) model versus MIPAS data intercomparison study, Atmos. Chem. Phys., 11, 90899139, https://doi.org/10.5194/acp-11-9089-2011, 2011.

Galle, B., Mellqvist, J., Arlander, D. W., Fløisand, I., Chipperfield, M. P., and Lee, A. M.: Ground Based FTIR Measurements of stratospheric species from Harestua, Norway during SESAME and Comparison with Models, J. Atmos. Chem., 32, 147-164, 1999.

Glatthor, N., Blom, C. E., Blumenstock, T., Fischer, H., Gulde, T., Höpfner, Kimmig, W., Piesch, C., Bell, W., Galle, B., and Wirth, M.: MIPAS-TRANSALL Observations of the Variability of $\mathrm{ClONO}_{2}$ During the Arctic Winter of 1994/95, J. Atmos. Chem., 30, 81-101, 1998.
Golden, D. M. and Smith, G. P.: Reaction of $\mathrm{OH}+\mathrm{NO}_{2}+\mathrm{M}$ : A new view, J. Phys. Chem. A, 104, 3991-3997, https://doi.org/10.1021/jp9939928, 2000.

Goldfarb, L., Harwood, M. H., Burkholder, J. B., and Ravishankara, A. R.: Reaction of $\mathrm{O}\left({ }^{3} \mathrm{P}\right)$ with $\mathrm{ClONO}_{2}$ : Rate Coefficients and Yield of $\mathrm{NO}_{3}$ Product, J. Phys. Chem. A, 102, 8556-8563, 1998.

Gordon, I. E., Rothman, L. S., Hill, C., Kochanov, R. V., Tan, Y., Bernath, P. F., Birk, M., Boudon, V., Campargue, A., Chance, K. V., Drouin, B. J., Flaud, J.-M., Gamache, R. R., Hodges, J. T., Jacquemart, D., Perevalov, V. I., Perrin, A., Shine, K. P., Smith, M.-A. H., Tennyson, J., Toon, G. C., Tran, H., Tyuterev, V. G., Barbe, A., Császár, A. G., Devi, V. M., Furtenbacher, T., Harrison, J. J., Hartmann, J.-M., Jolly, A., Johnson, T. J., Karman, T., Kleiner, I., Kyuberis, A. A., Loos, J., Lyulin, O. M., Massie, S. T., Mikhailenko, S. N., Moazzen-Ahmadi, N., Müller, H. S. P., Naumenko, O. V., Nikitin, A. V., Polyansky, O. L., Rey, M., Rotger, M., Sharpe, S. W., Sung, K., Starikova, E., Tashkun, S. A., Vander Auwera, J., Wagner, G., Wilzewski, J., Wcisło, P., Yu, S., and Zak, E. J.: The HITRAN2016 molecular spectroscopic database, J. Quant. Spectrosc. Ra., 203, 3-69, https://doi.org/10.1016/j.jqsrt.2017.06.038, 2017.

Grant, W. B., Fishman, J., Browell, E. V., Brackett, V. G., Nganga, D., Minga, A., Cros, B., Veiga, R. E., Butler, C. F., Fenn, M. A., and Nowicki, G. D.: Observations of reduced ozone concentrations in the tropical stratosphere after the eruption of Mt. Pinatubo, Geophys. Res. Lett., 19, 1109-1112, https://doi.org/10.1029/92GL01153, 1992.

Griesfeller, A., von Clarmann, T., Griesfeller, J., Höpfner, M., Milz, M., Nakajima, H., Steck, T., Sugita, T., Tanaka, T., and Yokota, T.: Intercomparison of ILAS-II version 1.4 and version 2 target parameters with MIPAS-Envisat measurements, Atmos. Chem. Phys., 8, 825-843, https://doi.org/10.5194/acp-8825-2008, 2008

Gunson, M. R. and Irion, F. W.: Measurement of atmospheric composition by the ATMOS instrument from Table Mountain Observatory, in: Remote Sensing of Atmospheric Chemistry, edited by: McElroy, J. L. and McNeal, R. J., vol. 1491, 335-346, https://doi.org/10.1117/12.46678, 1991.

Hampson, J.: Chemical Instability of the Stratosphere, paper presented at the International Association of Meteorology and Atmospheric Physics (IUGG) Symposium on Atmospheric Radiation, Leningrad, Russia, 1964.

Hanson, D. R. and Lovejoy, E. R.: The reaction of $\mathrm{ClONO}_{2}$ with submicrometer sulfuric acid aerosol, Science, 267, 1326-1328, 1995.

Hanson, D. R. and Ravishankara, A. R.: The Reaction Probabilities of $\mathrm{ClONO}_{2}$ and $\mathrm{N}_{2} \mathrm{O}_{5}$ on Polar stratospheric cloud materials, J. Geophys. Res., 96, 5081-5090, 1991a.

Hanson, D. R. and Ravishankara, A. R.: The reaction probabilities of $\mathrm{ClONO}_{2}$ and $\mathrm{N}_{2} \mathrm{O}_{5}$ on 40 to $75 \%$ sulfuric acid solutions, J. Geophys. Res.-Atmos., 96, 17307-17314, https://doi.org/10.1029/91JD01750, 1991b.

Hanson, D. R. and Ravishankara, A. R.: Heterogeneous chemistry of hydrogen bromide and hydrogen fluoride, J. Phys. Chem., 96, 9441-9446, https://doi.org/10.1021/j100202a069, 1992a.

Hanson, D. R. and Ravishankara, A. R.: Investigation of the reactive and nonreactive processes involving $\mathrm{ClONO}_{2}$ and $\mathrm{HCl}$ on water and nitric acid doped ice, J. Phys. Chem., 96, 2682-2691, 1992b. 
Hanson, D. R. and Ravishankara, A. R.: Reaction of $\mathrm{ClONO}_{2}$ with $\mathrm{HCl}$ on NAT, NAD, and frozen sulfuric acid and Hydrolysis of $\mathrm{N}_{2} \mathrm{O}_{5}$ and $\mathrm{ClONO}_{2}$ on Frozen sulfuric acid, J. Geophys. Res., 98, 22931-22936, 1993a.

Hanson, D. R. and Ravishankara, A. R.: Response to "Comment on porosities of ice films used to simulate stratospheric cloud surfaces", J. Phys. Chem., 97, 2802-2803, https://doi.org/10.1021/j100113a054, 1993b.

Hayashida, S., Sugita, T., Ikeda, N., Toda, Y., and Irie, H.: Temporal evolution of $\mathrm{ClONO}_{2}$ observed with Improved Limb Atmospheric Spectrometer (ILAS) during Arctic late winter and early spring in 1997, J. Geophys. Res., 112, D14311, https://doi.org/10.1029/2006JD008108, 2007.

Hegglin, M. I. and Tegtmeier, S. (Eds.): The SPARC Data Initiative: Assessment of stratospheric trace gas and aerosol climatologies from satellite limb sounders, SPARC Report No. 8, WCRP-5/2017, SPARC, https://doi.org/10.3929/ethz-a$010863911,2017$.

Hofmann, D. J., Oltmans, S. J., Komhyr, W. D., Harris, J. M., Lathrop, J. A., Langford, A. O., Deshler, T., Johnson, B. J., Torres, A., and Matthews, W. A.: Ozone loss in the lower stratosphere over the United States in 1992-1993: Evidence for heterogeneous chemistry on the Pinatubo aerosol, Geophys. Res. Lett., 21, 65-68, 1994.

Höpfner, M., von Clarmann, T., Fischer, H., Glatthor, N., Grabowski, U., Kellmann, S., Kiefer, M., Linden, A., Mengistu Tsidu, G., Milz, M., Steck, T., Stiller, G. P., Wang, D.-Y., and Funke, B.: First spaceborne observations of Antarctic stratospheric $\mathrm{ClONO}_{2}$ recovery: Austral spring 2002, J. Geophys. Res., 109, D11308, https://doi.org/10.1029/2004JD004609, 2004.

Höpfner, M., von Clarmann, T., Fischer, H., Funke, B., Glatthor, N., Grabowski, U., Kellmann, S., Kiefer, M., Linden, A., Milz, M., Steck, T., Stiller, G. P., Bernath, P., Blom, C. E., Blumenstock, Th., Boone, C., Chance, K., Coffey, M. T., Friedl-Vallon, F., Griffith, D., Hannigan, J. W., Hase, F., Jones, N., Jucks, K. W., Keim, C., Kleinert, A., Kouker, W., Liu, G. Y., Mahieu, E., Mellqvist, J., Mikuteit, S., Notholt, J., Oelhaf, H., Piesch, C., Reddmann, T., Ruhnke, R., Schneider, M., Strandberg, A., Toon, G., Walker, K. A., Warneke, T., Wetzel, G., Wood, S., and Zander, R.: Validation of MIPAS $\mathrm{ClONO}_{2}$ measurements, Atmos. Chem. Phys., 7, 257-281, https://doi.org/10.5194/acp-7-257-2007, 2007.

Irion, F. W., Gunson, M. R., Toon, G. C., Chang, A. Y., Eldering, A., Mahieu, E., Manney, G. L., Michelsen, H. A., Moyer, E. J., Newchurch, M. J., Osterman, G. B., Rinsland, C. P., Salawitch, R. J., Sen, B., Yung, Y. L., and Zander, R.: Atmospheric Trace Molecule Spectroscopy (ATMOS) Experiment Version 3 data retrievals, Appl. Optics, 41, 6968-6979, 2002.

Jackman, C. H., Douglass, A. R., Rood, R. B., McPeters, R. D., and Meade, P. E.: Effect of solor proton events on the middle atmosphere during the past two solar cycles as computed using a two-dimensional model, J. Geophys. Res., 95, 7417-7428, 1990.

Jackman, C. H., Fleming, E. L., and Vitt, F. M.: Influence of extremely large solar proton events in a changing stratosphere, J. Geophys. Res., 105, 11659-11670, 2000.

Johansson, S., Woiwode, W., Höpfner, M., Friedl-Vallon, F., Kleinert, A., Kretschmer, E., Latzko, T., Orphal, J., Preusse, P., Ungermann, J., Santee, M. L., Jurkat-Witschas, T., Marsing, A., Voigt, C., Giez, A., Krämer, M., Rolf, C., Zahn, A., Engel, A., Sinnhu- ber, B.-M., and Oelhaf, H.: Airborne limb-imaging measurements of temperature, $\mathrm{HNO}_{3}, \mathrm{O}_{3}, \mathrm{ClONO}_{2}, \mathrm{H}_{2} \mathrm{O}$ and CFC-12 during the Arctic winter 2015/2016: characterization, in situ validation and comparison to Aura/MLS, Atmos. Meas. Tech., 11, 4737-4756, https://doi.org/10.5194/amt-11-4737-2018, 2018.

Jones, A., Qin, G., Strong, K., Walker, K. A., McLinden, C. A., Toohey, M., Kerzenmacher, T., Bernath, P. F., and Boone, C. D.: A global inventory of stratospheric NOy from ACE-FTS, J. Geophys. Res., 116, D17304, https://doi.org/10.1029/2010JD015465, 2011.

Jones, R. L., Austin, J., McKenna, D. S., Anderson, J. G., Fahey, D. W., Farmer, C. B., Heidt, L. E., Kelly, K. K., Murphy, D. M., Proffitt, M. H., Tuck, A. F., and Vedder, J. F.: Lagrangian photochemical modeling studies of the 1987 Antarctica spring vortex 1. Comparison with AAOE observations, J. Geophys. Res., 94, 11529-11558, 1989.

Jurkat, T., Kaufmann, S., Voigt, C., Schäuble, D., Jeßberger, P., and Ziereis, H.: The airborne mass spectrometer AIMS Part 2: Measurements of trace gases with stratospheric or tropospheric origin in the UTLS, Atmos. Meas. Tech., 9, 1907-1923, https://doi.org/10.5194/amt-9-1907-2016, 2016.

Jurkat, T., Voigt, C., Kaufmann, S., Grooß, J., Ziereis, H., Dörnbrack, A., Hoor, P., Bozem, H., Engel, A., Bönisch, H., Keber, T., Hüneke, T., Pfeilsticker, K., Zahn, A., Walker, K. A., Boone, C. D., Bernath, P. F., and Schlager, H.: Depletion of ozone and reservoir species of chlorine and nitrogen oxide in the lower Antarctic polar vortex measured from aircraft, Geophys. Res. Lett., 44, 6440-6449, https://doi.org/10.1002/2017GL073270, 2017.

Kassel, L. S.: Studies in Homogeneous Gas Reactions I, J. Phys. Chem., 32, 225-242, https://doi.org/10.1021/j150284a007, 1928.

Kawa, S. R., Newman, P. A., Lait, L. R., Schoeberl, M. R., Stimpfle, R. M., Kohn, D. W., Webster, C. R., May, R. D., Baumgardner, D., Dye, J. E., Wilson, J. C., Chan, K. R., and Loewenstein, M.: Activation of chlorine in sulfate aerosol as inferred from aircraft observations, J. Geophys. Res., 102, 3921-3933, 1997.

Kinnison, D. E., Grant, K. E., Connell, P. S., Rotman, D. A., and Wuebbles, D. J.: The chemical and radiative effects of the Mount Pinatubo eruption, J. Geophys. Res., 99, 25705-25731, https://doi.org/10.1029/94JD02318, 1994.

Ko, M. K. W. and Sze, N. D.: Diurnal Variation of ClO: Implications for the Stratospheric Chemistries of $\mathrm{ClONO}_{2}, \mathrm{HOCl}$, and $\mathrm{HCl}, \mathrm{J}$. Geophys. Res., 89, 11619-11632, 1984.

Kohlhepp, R., Barthlott, S., Blumenstock, T., Hase, F., Kaiser, I., Raffalski, U., and Ruhnke, R.: Trends of $\mathrm{HCl}, \mathrm{ClONO}_{2}$, and HF column abundances from ground-based FTIR measurements in Kiruna (Sweden) in comparison with KASIMA model calculations, Atmos. Chem. Phys., 11, 4669-4677, https://doi.org/10.5194/acp-11-4669-2011, 2011.

Kohlhepp, R., Ruhnke, R., Chipperfield, M. P., De Mazière, M., Notholt, J., Barthlott, S., Batchelor, R. L., Blatherwick, R. D., Blumenstock, Th., Coffey, M. T., Demoulin, P., Fast, H., Feng, W., Goldman, A., Griffith, D. W. T., Hamann, K., Hannigan, J. W., Hase, F., Jones, N. B., Kagawa, A., Kaiser, I., Kasai, Y., Kirner, O., Kouker, W., Lindenmaier, R., Mahieu, E., Mittermeier, R. L., Monge-Sanz, B., Morino, I., Murata, I., Nakajima, H., Palm, M., Paton-Walsh, C., Raffalski, U., Reddmann, Th., Rettinger, M., Rinsland, C. P., Rozanov, E., 
Schneider, M., Senten, C., Servais, C., Sinnhuber, B.-M., Smale, D., Strong, K., Sussmann, R., Taylor, J. R., Vanhaelewyn, G., Warneke, T., Whaley, C., Wiehle, M., and Wood, S. W.: Observed and simulated time evolution of $\mathrm{HCl}, \mathrm{ClONO}_{2}$, and $\mathrm{HF}$ total column abundances, Atmos. Chem. Phys., 12, 3527-3556, https://doi.org/10.5194/acp-12-3527-2012, 2012.

Kurylo, M. J.: Flash photolysis resonance fluorescence investigation of the reaction of $\mathrm{O}\left({ }^{3} \mathrm{P}\right)$ atoms with $\mathrm{ClONO}_{2}$, Chem. Phys. Lett., 49, 467-470, https://doi.org/10.1016/00092614(77)87016-4, 1977

Lee, Y.-P., Stimpfle, R. M., Perry, R. A., Mucha, J. A., Evenson, K. M., Jennings, D. A., and Howard, C. J.: Laser magnetic resonance spectroscopy of $\mathrm{ClO}$ and kinetic studies of the reactions of $\mathrm{ClO}$ with $\mathrm{NO}$ and $\mathrm{NO}_{2}$, Int. J. Chem. Kinet., 14, 711-732, https://doi.org/10.1002/kin.550140612, 1982.

Leu, M.-T.: Kinetics of the reaction $\mathrm{Cl}+\mathrm{NO}_{2}+\mathrm{M}$, Int. J. Chem. Kinet., 16, 1311-1320, https://doi.org/10.1002/kin.550161103, 1984.

Leu, M.-T.: Laboratory studies of sticking Coefficients and Heterogeneous reactions important in the Antarctic stratosphere, Geophys. Res. Lett., 15, 17-20, 1988.

Mahieu, E., Zander, R., Duchatelet, P., Hannigan, J. W., Coffey, M. T., Mikuteit, S., Hase, F., Blumenstock, T., Wiacek, A., Strong, K., Taylor, J. R., Mittermeier, R. L., Fast, H., Boone, C. D., McLeod, S. D., Walker, K. A., Bernath, P. F., and Rinsland, C. P.: Comparisons between ACE-FTS and groundbased measurements of stratospheric $\mathrm{HCl}$ and $\mathrm{ClONO}_{2}$ loadings at northern latitudes, Geophys. Res. Lett., 32, L15S08, https://doi.org/10.1029/2005GL022396, 2005.

Mankin, W. G. and Coffey, M. T.: Airborne observations of chemical constituents in the Antarctic winter stratosphere, in: Ozone in the Atmosphere, Proceedings of the Quadrennial Ozone Symposium 1988 and Tropospheric Ozone Workshop, 4-13 August 1988, Göttingen, Germany, edited by: Bojkov, R. D. and Fabian, P., A. Deepak Publishing, Hampton, VA, USA, 1989.

Mankin, W. G., Coffey, M. T., Goldman, A., Schoeberl, M. R., Lait, L. R., and Newman, P. A.: Airborne Measurements of stratospheric constituents over the Arctic in the winter of 1989, Geophys. Res. Lett., 17, 473-476, 1990.

Manney, G. L., Froidevaux, L., Waters, J. W., Zurek, R. W., Read, W. G., Elson, L. S., Kumer, J. B., Mergenthaler, J. L., Roche, A. E., O'Neill, A., Harwood, R. S., MacKenzie, I., and Swinbank, R.: Chemical depletion of ozone in the Arctic lower stratosphere during winter 1992-93, Nature, 370, 429-434, 1994.

Marcus, R. A.: Unimolecular Dissociations and Free Radical Recombination Reactions, J. Chem. Phys., 20, 359-364, https://doi.org/10.1063/1.1700424, 1952.

Marcy, T. P., Gao, R. S., Northway, M. J., Popp, P. J., Stark, H., and Fahey, D. W.: Using chemical ionization mass spectrometry for detection of $\mathrm{HNO}_{3}, \mathrm{HCl}$, and $\mathrm{ClONO}_{2}$ in the atmosphere, Int. J. Mass Spectrom., 243, 63-70, https://doi.org/10.1016/j.ijms.2004.11.012, 2005.

Margitan, J. J.: Chlorine nitrate photochemistry. Photolysis products and kinetics of the reaction $\mathrm{Cl}+\mathrm{ClONO}_{2} \longrightarrow \mathrm{Cl}_{2}+\mathrm{NO}_{3}, \mathrm{~J}$. Phys. Chem., 87, 674-679, https://doi.org/10.1021/j100227a029, 1983.

Martin, H.: Bildungsreaktionen des Nitroxylchlorids, Angew. Chem., 70, 97-98, https://doi.org/10.1002/ange.19580700403, 1958.
Martin, H. and Jacobsen, T.: Über die Bildung von $\mathrm{NO}_{3} \mathrm{Cl}$ bei Reaktionen zwischen Chlordioxyd und Oxyden des Stickstoffs, Angew. Chem., 67, p. 524, 1955.

McCormick, M. P., Steele, H. M., Hamill, P., Chu, W. P., and Swissler, T. J.: Polar stratospheric cloud sightings by SAM II, J. Atmos. Sci, 39, 1387-1397, 1982.

McCormick, M. P., Thomason, L. W., and Trepte, C. R.: Atmospheric effects of the Mt. Pinatubo eruption, Nature, 373, 399404, https://doi.org/10.1038/373399a0, 1995.

McElroy, M. B., Salawitch, R. J., and Wofsy, S. C.: Antarctic $\mathrm{O}_{3}$ : Chemical mechanisms for spring decrease, Geophys. Res. Lett., 13, 1296-1299, 1986a.

McElroy, M. B., Salawitch, R. J., Wofsy, S. C., and Logan, J. A.: Reductions of Antarctic ozone due to synergistic interactions of chlorine and bromine, Nature, 321, 759-762, https://doi.org/10.1038/321759a0, 1986b.

Mellqvist, J., Galle, B., Blumenstock, T., Hase, F., Yashcov, D., Notholt, J., Sen, B., Blavier, J.-F., Toon, G. C., and Chipperfield, M. P.: Ground-Based FTIR observations of chlorine activation and ozone depletion inside the Arctic vortex during the winter of 1999/2000, J. Geophys. Res., 107, SOL 6-1-SOL 616, https://doi.org/10.1029/2001JD001080, 2002.

Michelsen, H. A., Webster, C. R., Manney, G. L., Scott, D. C., Margitan, J. J., May, R. D., Irion, F. W., Gunson, M. R., Russell III, J. M., and Spivakovsky, C. M.: Maintenace of high $\mathrm{HCl} / \mathrm{Cl}_{y}$ and $\mathrm{NO}_{x} / \mathrm{NO}_{y}$ in the Antarctic vortex: A chemical signature of confinement during spring, J. Geophys. Res., 104, 26419-26436, 1999.

Molina, L. T. and Molina, M. J.: Production of $\mathrm{Cl}_{2} \mathrm{O}_{2}$ from the SelfReaction of the ClO Radical, J. Phys. Chem. A, 91, 433-436, 1987.

Molina, L. T., Spencer, J. E., and Molina, M. J.: The rate constant for the reaction of $\mathrm{O}\left({ }^{3} \mathrm{P}\right)$ atoms with $\mathrm{ClONO}_{2}$, Chem. Phys. Lett, 45, 158-162, https://doi.org/10.1016/0009-2614(77)85233$0,1977$.

Molina, M. J.: Role of Chlorine in Stratospheric Chemistry, Pure Appl. Chem., 68, 1749-1756, https://doi.org/10.1351/pac199668091749, 1996.

Molina, M. J. and Rowland, F. S.: Stratospheric sink for chlorofluoromethanes: Chlorine atom-catalysed destruction of ozone, Nature, 249, 810-812, 1974.

Molina, M. J., Molina, L. T., and Ishiwata, T.: Kinetics of the $\mathrm{ClO}+\mathrm{NO}_{2}+\mathrm{M}$ reaction, J. Phys. Chem., 84, 3100-3104, https://doi.org/10.1021/j100460a026, 1980.

Molina, M. J., Tso, T.-L., Molina, L. T., and Wang, F. C.-Y.: Antarctic Stratospheric Chemistry of Chlorine Nitrate, Hydrogen Chloride, and Ice: Release of Active Chlorine, Science, 238, 1253 1257, https://doi.org/10.1126/science.238.4831.1253, 1987.

Molina, M. J., Molina, L. T., Zhang, R., Meads, R. F., and Spencer, D. D.: The reaction of $\mathrm{ClONO}_{2}$ with $\mathrm{HCl}$ on aluminium oxide, Geophys. Res. Lett., 24, 1619-1622, 1997.

Moore, T. A., Okumura, M., Tagawa, M., and K., T.: Dissociation dynamics of $\mathrm{ClONO}_{2}$ and relative $\mathrm{Cl}$ and $\mathrm{ClO}$ product yields following photoexcitation at $308 \mathrm{~nm}$, Faraday Discuss., 100, 295307, https://doi.org/10.1039/FD9950000295, 1995.

Müller, R., Peter, T., Crutzen, P. J., Oelhaf, H., Adrian, G. P., von Clarmann, T., Wegner, A., Schmidt, U., and Lary, D.: Chlorine chemistry and the potential for ozone depletion in the Arctic 
stratosphere in the winter of 1991/92, Geophys. Res. Lett., 21, 1427-1430, 1994.

Murcray, D. G., Goldman, A., Williams, W. J., Murcray, F. H., Bonomo, F. S., Bradford, C. M., Cook, G. R., Hanst, P. L., and Molina, M. J.: Upper limit for stratospheric $\mathrm{CLONO}_{2}$ from balloon-borne infrared measurements, Geophys. Res. Lett., 4, 227-230, https://doi.org/10.1029/GL004i006p00227, 1977.

Murcray, D. G., Williams, J. W., Barker, D. B., Goldman, A., Bradford, C. M., and Cook, G. R.: Measurements of Constituents of Interest in the Photochemistry of the Ozone Layer Using Infrared Techniques, in: Papers presented at the WMO Symposium on the Geophysical Aspects and Consequences of Changes in the Composition of the Stratosphere, 26-30 June 1978, Toronto, Canada Secretariat of the World Meteorological Organization, Geneva, Switzerland, 61-68, 1978.

Murcray, D. G., Goldman, A., Murcray, F. H., Murcray, F. J., and Williams, W. J.: Stratospheric Distribution of $\mathrm{ClONO}_{2}$, Geophys. Res. Lett., 6, 857-859, 1979.

Nakajima, H., Sugita, T., Irie, H., Saitoh, N., Kanzawa, H., Oelhaf, H., Wetzel, G., Toon, G. C., Sen, B., Blavier, J.-F., Traub, W. A., Jucks, K., Johnson, D. G., Yokota, T., and Sasano, Y.: Measurements of $\mathrm{ClONO}_{2}$ by the Improved Limb Atmospheric Spectrometer (ILAS) in high-latitude stratosphere: New products using version 6.1 data processing algorithm, J. Geophys. Res., 111, D11S19, https://doi.org/10.1029/2005JD006441, 2006.

Nassar, R., Bernath, P. F., Boone, C. D., Clerbaux, C., Coheur, P. F., Dufour, G., Froidevaux, L., Mahieu, E., McConnell, J. C., McLeod, S. D., Murtagh, D. P., Rinsland, C. P., Semeniuk, K., Skelton, R., Walker, K. A., and Zander, R.: A global inventory of stratospheric chlorine in 2004, J. Geophys. Res., 111, D22312, https://doi.org/10.1029/2006JD007073, 2006.

Nelson, C. M., Moore, T. A., Okumura, M., and Minton, T. K.: Photodissociation of $\mathrm{ClONO}_{2}$ at 193 and $248 \mathrm{~nm}$, Chem. Phys., 207, 287-308, https://doi.org/10.1016/0301-0104(95)00383-5, 1996.

Nickolaisen, S. L., Sander, S. P., and Friedl, R. R.: Pressuredependent yields and product branching ratios in the broadband photolysis of chlorine nitrate, J. Phys. Chem., 100, 1016510178, https://doi.org/10.1021/jp953612s, 1996.

Notholt, J.: FTIR measurements of HF, $\mathrm{N}_{2} \mathrm{O}$ and CFCs during the Artic polar night with the moon as light source, subsidence during winter 1992/93, Geophys. Res. Lett., 21, 2385-2388, 1994.

Notholt, J., Neuber, R., Schrems, O., and von Clarmann, T.: Stratospheric Trace Gas Concentrations in the Arctic Polar Night Derived by FTIR-Spectroscopy With the Moon as IR Light Source, Geophys. Res. Lett., 20, 2059-2062, https://doi.org/10.1029/93GL01971, 1993.

Notholt, J., von Clarmann, T., Adrian, G. P., and Schrems, O.: Ground-based FTIR measurements of $\mathrm{ClONO}_{2}$ vertical column amounts in the Arctic, Geophys. Res. Lett., 21, 1359-1362, https://doi.org/10.1029/93GL01785, 1994.

Notholt, J., von der Gathen, P., and Peil, S.: Heterogeneous conversion of $\mathrm{HCl}$ and $\mathrm{ClONO}_{2}$ during the Arctic winter 1992/1993 initiating ozone depletion, J. Geophys. Res., 100, 11269-11274, 1995.

Notholt, J., Toon, G., Lehmann, R., Sen, B., and Blavier, J.-F.: Comparison of Arctic and Antarctic trace gas column abundances from ground-based Fourier transform infrared spectrometer, J. Geophys. Res., 102, 12863-12869, 1997.
Oelhaf, H., von Clarmann, T., Fischer, H., Friedl-Vallon, F., Frietzsche, C., Linden, A., Piesch, C., Seefeldner, M., and Völker, W.: Stratospheric $\mathrm{ClONO}_{2}$ and $\mathrm{HNO}_{3}$ profiles inside the Arctic vortex from MIPAS-B limb emission spectra obtained during EASOE, Geophys. Res. Lett., 21, 1263-1266, 1994.

Payan, S., Camy-Peyret, C., Jeseck, P., Hawat, T., and Durry, G.: First direct simultaneous $\mathrm{HCl}$ and $\mathrm{ClONO}_{2}$ profile measurements in the Arctic vortex, Geophys. Res. Lett., 25, 2663-2666, 1998.

Pfeilsticker, K., Blom, C. E., Brandtjen, R., Glatthor, N., Grendel, A., Gulde, T., Höpfner, M., Perner, D., Piesch, C., Platt, U., Renger, W., Sessler, J., and Wirth, M.: Aircraft-borne detection of stratospheric column amounts of $\mathrm{O}_{3}, \mathrm{NO}_{2}, \mathrm{OClO}, \mathrm{ClNO}_{3}$, $\mathrm{HNO}_{3}$ and aerosols around the arctic vortex $\left(79^{\circ} \mathrm{N}\right.$ to $\left.39^{\circ} \mathrm{N}\right)$ during spring 1993, 1. Observational data, J. Geophys. Res., 102, 10801-10814, 1997.

Pitari, G., Visconti, G., and Rizi, V.: Sensitivity of stratospheric ozone to heterogeneous chemistry on sulfate aerosols, Geophys. Res. Lett., 18, 833-836, 1991.

Portmann, R. W., Solomon, S., Garcia, R. R., Thomason, L. W., Poole, L. R., and McCormick, M. P.: Role of aerosol variations in anthropogenic ozone depletion in polar regions, J. Geophys. Res., 101, 22991-23006, https://doi.org/10.1029/96JD02608, 1996.

Prather, M. J.: Catastrophic Loss of Stratospheric Ozone in Dense Volcanic Clouds, J. Geophys. Res., 97, 10187-10191, 1992.

Randel, W. J., Wu, F., Russell III, J. M., Waters, J., and Froidevaux, L.: Ozone and temperature changes in the stratosphere following the eruption of Mount Pinatubo, J. Geophys. Res., 100, 1675316764, 1995.

Rankin, D. W. H. and Robertson, H. E.: Gas-phase molecular structures determined by electron diffraction, in: Spectroscopic Properties of Inorganic and Organometallic Compounds, edited by: Davidson, G., Roy. Soc. Chem., 27, 438-458, https://doi.org/10.1039/9781847555113-00438, 1994.

Raspollini, P., Carli, B., Carlotti, M., Ceccherini, S., Dehn, A., Dinelli, B. M., Dudhia, A., Flaud, J.-M., López-Puertas, M., Niro, F., Remedios, J. J., Ridolfi, M., Sembhi, H., Sgheri, L., and von Clarmann, T.: Ten years of MIPAS measurements with ESA Level 2 processor V6 - Part 1: Retrieval algorithm and diagnostics of the products, Atmos. Meas. Tech., 6, 2419-2439, https://doi.org/10.5194/amt-6-2419-2013, 2013.

Ravishankara, A. R.: Contribution to the 'General Discussion' led by Prof. Wodtke, Faraday Discuss., 100, 335-336, 1995.

Reisinger, A. R., Jones, N. B., and Matthews, W. A.: Southern hemisphere midlatitude ground-based measurements of $\mathrm{ClONO}_{2}$ : Method of analysis, seasonal cycle and long term-trend, J. Geophys. Res., 100, 23183-23193, 1995.

Rex, M., Harris, N. R. P., von der Gathen, P., Lehmann, R., Braathen, G. O., Reimer, E., Beck, A., Chipperfield, M. P., Alfier, R., Allaart, M., O’Connor, F., Dier, H., Dorokhov, V., Fast, H., Gil, M., Kyrö, E., Litynska, Z., Mikkelsen, I. S., Molyneux, M. G., Nakane, H., Notholt, J., Rummukainen, M., Viatte, P., and Wenger, J.: Prolonged stratospheric ozone loss in the 199596 Arctic winter, Nature, 389, 835-838, 1997.

Rice, O. K. and Ramsperger, H. C.: Theories of unimolecular gas reactions at low pressures, J. Am. Chem. Soc., 49, 1617-1629, https://doi.org/10.1021/ja01406a001, 1927.

Riese, M., Preusse, P., Spang, R., Ern, M., Jarnish, M., Grossmann, K. U., and Offermann, D.: Measurements of trace gases by the 
Cryogenic Infrared Spectrometers and Telescopes (CRISTA) experiment, Adv. Space Res., 19, 563-566, 1997.

Riese, M., Spang, R., Preusse, P., Ern, M., Jarnish, M., Offermann, D., and Grossmann, K. U.: Cryogenic Infrared Spectrometers and Telescopes for the Atmosphere (CRISTA) data processing and atmospheric temperature and trace gas retrieval, J. Geophys. Res., 104, 16349-16367, 1999.

Riese, M., Friedl-Vallon, F., Spang, R., Preusse, P., Schiller, C., Hoffmann, L., Konopka, P., Oelhaf, H., von Clarmann, T., and Höpfner, M.: GLObal limb Radiance Imager for the Atmosphere (GLORIA): Scientific objectives, Adv. Space Res., 36, 989-995, https://doi.org/10.1016/j.asr.2005.04.115, 2005.

Rinsland, C. P., Goldman, A., Murcray, D. G., Murcray, F. J., Bonomo, F. S., Blatherwick, R. D., Malathy Devi, V., Smith, M. A. H., and Rinsland, P. L.: Tentative Identification of the 780$\mathrm{cm}^{-1} v_{4} \mathrm{Q}$ branch of chlorine nitrate in high resolution solar absorption spectra of the stratosphere, J. Geophys. Res., 90, 79317943, https://doi.org/10.1029/JD090iD05p07931, 1985.

Rinsland, C. P., Gunson, M. R., Abrams, M. C., Zander, R., Mahieu, E., Goldman, A., Ko, M. K. W., Rodriguez, J. M., and Sze, N. D.: Profiles of stratospheric chlorine nitrate $\left(\mathrm{ClONO}_{2}\right)$ from atmospheric trace molecule spectroscopy/ATLAS 1 infrared solar occultation spectra, J. Geophys. Res., 99, 18895-18900, 1994.

Rinsland, C. P., Gunson, M. R., Abrams, M. C., Lowes, L. L., Zander, R., Mahieu, E., Goldman, A., and Irion, F. W.: April 1993 Arctic profiles of stratospheric $\mathrm{HCl}, \mathrm{ClONO}_{2}$, and $\mathrm{CCl}_{2} \mathrm{~F}_{2}$ from atmospheric trace molecule spectroscopy/ATLAS 2 infrared solar occultation spectra, J. Geophys. Res., 100, 14019-14027, 1995.

Rinsland, C. P., Gunson, M. R., Salawitch, R. J., Michelsen, H. A., Zander, R., Newchurch, M. J., Abbas, M. M., Abrams, M. C., Manney, G. L., Chang, A. Y., Irion, F. W., Goldman, A., and Mahieu, E.: ATMOS/ATLAS-3 measurements of stratospheric chlorine and reactive nitrogen partitioning inside and outside the November 1994 Antarctic vortex, Geophys. Res. Lett., 23, 23652368, 1996a.

Rinsland, C. P., Zander, R., Demoulin, P., and Mahieu, E.: $\mathrm{ClONO}_{2}$ total vertical column abundances above the Jungfraujoch Station 1986-1994: Long-term trend and winter-spring enhancements, J. Geophys. Res., 101, 3891-3899, 1996b.

Rinsland, C. P., Mahieu, E., Zander, R., Jones, N. B., Chipperfield, M. P., Goldman, A., Anderson, J., Russell III, J. M., Demoulin, P., Notholt, J., Toon, G. C., Blavier, J.-F., Sen, B., Sussmann, R., Wood, S. W., Meier, A., Griffith, D. W. T., Chiou, L. S., Murcray, F. J., Stephen, T. M., Hase, F., Mikuteit, S., Schulz, A., and Blumenstock, T.: Long-term trends of inorganic chlorine from ground-based infrared solar spectra: Past increases and evidence for stabilization, J. Geophys. Res., 108, 4252, https://doi.org/10.1029/2002JD003001, 2003.

Rinsland, C. P., Chiou, L. S., Goldman, A., and Hannigan, J. W.: Multi-decade measurements of the long-term trends of atmospheric species by high-spectral-resolution infrared solar absorption spectroscopy, J. Quant. Spectrosc. Ra., 111, 376-383, https://doi.org/10.1016/j.jqsrt.2009.09.012, 2010.

Robinson, G. N., Worsnop, D. R., Jayne, J. T., Kolb, C. E., and Davidovits, P.: Heterogeneous uptake of $\mathrm{ClONO}_{2}$ and $\mathrm{N}_{2} \mathrm{O}_{5}$ by sulfuric acid solutions, J. Geophys. Res., 102, 3583-3601, 1997.

Roche, A. E., Kumer, J. B., and Mergenthaler, J. L.: CLAES observations of $\mathrm{CLONO}_{2}$ and $\mathrm{HNO}_{3}$ in the Antarctic stratosphere, between June 15 and September 17, 1992, Geophys. Res. Lett., 20, 1223-1226, 1993.

Roche, A. E., Kumer, J. B., Mergenthaler, J. L., Nightingale, R. W., Uplinger, W. G., Ely, G. A., Potter, J. F., Wuebbles, D. J., Connell, P. S., and Kinnison, D. E.: Observations of lowerstratospheric $\mathrm{ClONO}_{2}, \mathrm{HNO}_{3}$, and aerosol by the UARS CLAES experiment between January 1992 and April 1993, J. Atmos. Sci., 51, 2877-2902, 1994.

Rothman, L. S., Jacquemart, D., Barbe, A., Benner, D. C., Birk, M., Brown, L. R., Carleer, M. R., Chackerian Jr., C., Chance, K., Coudert, L. H., Dana, V., Devi, V. M., Flaud, J.M., Gamache, R. R., Goldman, A., Hartmann, J.-M., Jucks, K. W., Maki, A. G., Mandin, J.-Y., Massie, S. T., Orphal, J., Perrin, A., Rinsland, C. P., Smith, M. A. H., Tennyson, J., Tolchenov, R. N., Toth, R. A., Vander Auwera, J., Varanasi, P., and Wagner, G.: The HITRAN 2004 molecular spectroscopic database, J. Quant. Spectrosc. Ra., 96, 139-204, https://doi.org/10.1016/j.jqsrt.2004.10.008, 2005.

Rowland, F. S., Spencer, J. E., and Molina, M. J.: Stratospheric formation and photolysis of chlorine nitrate, J. Phys. Chem., 80, 2711-2713, https://doi.org/10.1021/j100565a019, 1976.

Salawitch, R. J., Wofsy, S. C., and McElroy, M. B.: Influence of Polar Stratospheric Clouds on the Depletion of Antarctic Ozone, Geophys. Res. Lett., 15, 871-874, 1988.

Salawitch, R. J., Wofsy, S. C., Gottlieb, E. W., Lait, L. R., Newman, P. A., Schoeberl, M. R., Loewenstein, M., Podolske, J. R., Strahan, S. E., Proffitt, M. H., Webster, C. R., May, R. D., Fahey, D. W., Baumgardner, D., Dye, J. E., Wilson, J. C., Kelly, K. K., Elkins, J. W., Chan, K. R., and Anderson, J. G.: Chemical loss of ozone in the Arctic polar vortex in the winter of 1991-1992, Science, 261, 1146-1149, 1993.

Sander, R., Rudich, Y., von Glasgow, R., and Crutzen, P. J.: The role of $\mathrm{BrNO}_{3}$ in marine tropospheric chemistry: A model study, Geophys. Res. Lett., 26, 2857-2860, https://doi.org/10.1029/1999GL900478, 1999.

Santee, M. L., Froidevaux, L., Manney, G. L., Read, W. G., Waters, J. W., Chipperfield, M. P., Roche, A. E., Kumer, J. B., Mergenthaler, J. L., and Russell III, J. M.: Chlorine deactivation in the lower stratospheric polar regions during late winter: Results from UARS, J. Geophys. Res., 101, 18835-18859, 1996.

Santee, M. L., Tabazadeh, A., Manney, G. L., Salawitch, R. J., Froidevaux, L., Read, W. G., and Waters, J. W.: UARS Microwave Limb Sounder $\mathrm{HNO}_{3}$ observations: Implications for Antarctic polar stratospheric clouds, J. Geophys. Res., 103, 13285-13313, 1998.

Santee, M. L., MacKenzie, I. A., Manney, G. L., Chipperfield, M. P., Bernath, P. F., Walker, K. A., Boone, C. D., Froidevaux, L., Livesey, N. J., and Waters, J. W.: A study of stratospheric chlorine partitioning based on new satellite measurements and modeling, J. Geophys. Res., 113, D12307, https://doi.org/10.1029/2007JD009057, 2008.

Sen, B., Osterman, G. B., Salawitch, R. J., Toon, G. C., Margitan, J. J., Blavier, J.-F., Chang, A. Y., May, R. D., Webster, C. R., Stimpfle, R. M., Bonne, G. P., Voss, P. B., Perkins, K. K., Anderson, J. G., Cohen, R. C., Elkins, J. W., Dutton, G. S., Hurst, D. F., Romashkin, P. A., Atlas, E. L., Schauffler, S. M., and Loewenstein, M.: The budget and partitioning of stratospheric chlorine during the 1997 Arctic summer, J. Geophys. Res., 104, 26653 26665, 1999. 
Sheese, P. E., Walker, K. A., Boone, C. D., McLinden, C. A., Bernath, P. F., Bourassa, A. E., Burrows, J. P., Degenstein, D. A., Funke, B., Fussen, D., Manney, G. L., McElroy, C. T., Murtagh, D., Randall, C. E., Raspollini, P., Rozanov, A., Russell III, J. M., Suzuki, M., Shiotani, M., Urban, J., von Clarmann, T., and Zawodny, J. M.: Validation of ACE-FTS version $3.5 \mathrm{NO}_{y}$ species profiles using correlative satellite measurements, Atmos. Meas. Tech., 9, 5781-5810, https://doi.org/10.5194/amt-9-5781-2016, 2016.

Shi, Q., Jayne, J. T., Kolb, C. E., Worsnop, D. R., and Davidovits, P.: Kinetic model for reaction of $\mathrm{ClONO}_{2}$ with $\mathrm{H}_{2} \mathrm{O}$ and $\mathrm{HCl}$ and $\mathrm{HOCl}$ with $\mathrm{HCl}$ in sulfuric acid solutions, J. Geophys. Res., 106, 24259-24274, https://doi.org/10.1029/2000JD000181, 2001.

Solomon, P. M., de Zafra, R., Parrish, A., and Barrett, J. W.: Diurnal Variation of Stratospheric Chlorine Monoxide: A Critical Test of Chlorine Chemistry in the Ozone Layer, Science, 224, 12101214, https://doi.org/10.1126/science.224.4654.1210, 1984.

Solomon, P. M., Connor, B., de Zafra, R. L., Parrish, A., Barrett, J., and Jaramillo, M.: High concentrations of chlorine monoxide at low altitudes in the Antarctic spring stratosphere: Secular variation, Nature, 328, 411-413, 1987.

Solomon, S.: Antarctic ozone: Progress towards a quantitative understanding, Nature, 347, 347-354, 1990.

Solomon, S.: Stratospheric Ozone Depletion: A Review of Concepts and History, Rev. Geophys., 37, 275-315, 1999.

Solomon, S. and Crutzen, P. J.: Analysis of the August 1972 Solar Proton Event Including Chlorine Chemistry, J. Geophys. Res., 86, 1140-1146, 1981.

Solomon, S., Garcia, R. R., Rowland, F. S., and Wuebbles, D. J.: On the depletion of Antarctic ozone, Nature, 321, 755-758, 1986.

Solomon, S., Kinnison, D., Bandoro, J., and Garcia, R.: Simulation of polar ozone depletion: An update, J. Geophys. Res.-Atmos., 120, 7958-7974, https://doi.org/10.1002/2015JD023365, 2015.

Solomon, S., Kinnison, D., Garcia, R. R., Bandoro, J., Mills, M., Wilka, C., Neely III, R. R., Schmidt, A., Barnes, J. E., Vernier, J., and Höpfner, M.: Monsoon circulations and tropical heterogeneous chlorine chemistry in the stratosphere, Geophys. Res. Lett., 43, 12624-12633, https://doi.org/10.1002/2016GL071778, 2016.

Spang, R., Riese, M., and Offermann, D.: CRISTA-2 observations of the south polar vortex in winter 1997: A new dataset for polar process studies, Geophys. Res. Lett., 28, 3159-3162, 2001.

Stiller, G. P. (Ed.): The Karlsruhe Optimized and Precise Radiative Transfer Algorithm (KOPRA), vol. FZKA 6487 of Wissenschaftliche Berichte, Forschungszentrum Karlsruhe, Karlsruhe, Germany, 2000.

Stimpfle, R. M., Cohen, R. C., Bonne, G. P., Voss, P. B., Perkins, K. K., Koch, L. C., Anderson, J. G., Salawitch, R. J., Lloyd, S. A., Gao, R. S., DelNegro, L. A., Keim, E. R., and Bui, T. P.: The coupling of $\mathrm{ClONO}_{2}, \mathrm{ClO}$, and $\mathrm{NO}_{2}$ in the lower stratosphere from in situ observations using the NASA ER-2 aircraft, J. Geophys. Res., 104, 26705-26714, 1999.

Stolarski, R. S. and Cicerone, R. J.: Stratospheric chlorine: A possible sink for ozone, Cand. J. Chem., 52, 1610-1615, 1974.

Størmer, C.: Remarkable Clouds at High Altitudes, Nature, 123, 260-261, https://doi.org/10.1038/123260a0, 1929.

Størmer, C.: Mother-of-Pearl Clouds over Scandinavia in January and February 1932, Nature, 129, p. 941, https://doi.org/10.1038/129941a0, 1932.
Stroh, F., Heinecke, F., Afchine, A., Barthel, J., Engel, A., Grooß, J.-U., von Hobe, M., Schönfeld, A. R. A., Suminska, O., and Tan, V.: Balloon-borne In-Situ Measurements of $\mathrm{ClO}$ and $\mathrm{ClONO}_{2}$ in the late 2010/2011 Arctic Polar Vortex: instrument Calibration and Results, AGU, Washington, D.C., USA, 2011.

Tang, M., Keeble, J., Telford, P. J., Pope, F. D., Braesicke, P., Griffiths, P. T., Abraham, N. L., McGregor, J., Watson, I. M., Cox, R. A., Pyle, J. A., and Kalberer, M.: Heterogeneous reaction of $\mathrm{ClONO}_{2}$ with $\mathrm{TiO}_{2}$ and $\mathrm{SiO}_{2}$ aerosol particles: implications for stratospheric particle injection for climate engineering, Atmos. Chem. Phys., 16, 15397-15412, https://doi.org/10.5194/acp-1615397-2016, 2016.

Tie, X. X. and Brasseur, G.: The importance of heterogeneous bromine chemistry in the lower stratosphere, Geophys. Res. Lett., 23, 2505-2508, 1996.

Tolbert, M. A., Rossi, M. J., Malhotra, R., and Golden, D. M.: Reaction of Chlorine Nitrate with Hydrogen Chloride and Water at Antarctic Stratospheric Temperatures, Science, 238, 1258-1260, https://doi.org/10.1126/science.238.4831.1258, 1987.

Tolbert, M. A., Rossi, M. J., and Golden, D. M.: Heterogeneous interactions of chlorine nitrate, hydrogen chloride, and nitric acid with sulfuric acid surfaces at stratospheric temperatures, Geophys. Res. Lett., 15, 847-850, 1988.

Toon, G. C., Farmer, C. B., Lowes, L. L., Schaper, P. W., Blavier, J.-F., and Norton, R. H.: Infrared aircraft measurements of stratospheric composition over Antarctica during September 1987, J. Geophys. Res., 94, 16571-16596, 1989.

Toon, G. C., Farmer, C. B., Schaper, P. W., Lowes, L. L., and Norton, R. H.: Composition measurements of the 1989 Arctic winter stratosphere by airborne infrared solar absorption spectroscopy, J. Geophys. Res., 97, 7939-7961, 1992.

Toon, G. C., Blavier, J.-F., Solario, J. N., and Szeto, J. T.: Airborne observations of the 1992 Arctic winter stratosphere by FTIR solar absorption spectroscopy, in: Optical Methods in Atmospheric Chemistry, vol. 1715, 457-467, Society of Photo-Optical Instrumentation Engineers, Bellingham, Wash., USA, 1993.

Toon, G. C., Blavier, J.-F., and Szeto, J. T.: Latitude variations of stratospheric trace gases, Geophys. Res. Lett., 21, 2599-2602, 1994.

Toon, G. C., Blavier, J.-F., Sen, B., Margitan, J. J., Webster, C. R., May, R. D., Fahey, D., Gao, R., DelNegro, L., Proffitt, M., Elkins, J., Romashkin, P. A., Hurst, D. F., Oltmans, S., Atlas, E., Schauffler, S., Flocke, F., Bui, T. P., Stimpfle, R. M., Bonne, G. P., Voss, P. B., and Cohen, R. C.: Comparison of MkIV balloon and ER2 aircraft measurements of atmospheric trace gases, J. Geophys. Res., 104, 26779-26790, 1999.

Toon, G. C., Sen, B., Blavier, J.-F., Sasano, Y., Yokota, T., Kanzawa, H., Ogawa, T., Suzuki, M., and Shibasaki, K.: Comparison of ILAS and MkIV profiles of atmospheric trace gases measured above Alaska in May 1997, J. Geophys. Res., 107, ILS 8-1-ILS 8-6, https://doi.org/10.1029/2001JD000640, 2002.

Toon, O. B., Hamill, P., Turco, R. P., and Pinto, J.: Condensation of $\mathrm{HNO}_{3}$ and $\mathrm{HCl}$ in the winter polar stratospheres, Geophys. Res. Lett., 13, 1284-1287, 1986.

Toon, O. B., Turco, R. P., and Hamill, P.: Denitrification Mechanisms in the Polar Stratospheres, Geophys. Res. Lett., 17, 445448, 1990.

Toon, O. B., Browell, E., Gary, B., Lait, L., Livingston, J., Newman, P., Pueschel, R., Russell, P., Schoeberl, M., Toon, G., Traub, W., 
Valero, F. P. J., Selkirk, H., and Jordan, J.: Heterogeneous reaction probabilities, solubilities, and the physical state of cold volcanic aerosols, Science, 261, 1136-1140, 1993.

Toumi, R., Jones, R. L., and Pyle, J. A.: Stratospheric ozone depletion by $\mathrm{ClONO}_{2}$ photolysis, Nature, 365, 37-39, 1993.

Ungermann, J., Kalicinsky, C., Olschewski, F., Knieling, P., Hoffmann, L., Blank, J., Woiwode, W., Oelhaf, H., Hösen, E., Volk, C. M., Ulanovsky, A., Ravegnani, F., Weigel, K., Stroh, F., and Riese, M.: CRISTA-NF measurements with unprecedented vertical resolution during the RECONCILE aircraft campaign, Atmos. Meas. Tech., 5, 1173-1191, https://doi.org/10.5194/amt-51173-2012, 2012.

Virolainen, Y. A., Timofeev, Y. M., Poberovskii, A. V., Kirner, O., and Höpfner, M.: Chlorine Nitrate in the Atmosphere over St. Petersburg, Izv. Atmos. Ocean. Phy.+, 51, 49-56, 2015.

von Clarmann, T.: Chlorine in the stratosphere, Atmósfera, 26, 415458, 2013.

von Clarmann, T., Fischer, H., Friedl-Vallon, F., Linden, A., Oelhaf, H., Piesch, C., Seefeldner, M., and Völker, W.: Retrieval of Stratospheric $\mathrm{O}_{3}, \mathrm{HNO}_{3}$ and $\mathrm{ClONO}_{2}$ Profiles From 1992 MIPAS-B Limb Emission Spectra: Method, Results and Error Analysis, J. Geophys. Res., 98, 20495-20506, 1993.

von Clarmann, T., Wetzel, G., Oelhaf, H., Friedl-Vallon, F., Linden, A., Maucher, G., Seefeldner, M., Trieschmann, O., and Lefèvre, F.: $\mathrm{ClONO}_{2}$ vertical profile and estimated mixing ratios of $\mathrm{ClO}$ and $\mathrm{HOCl}$ in winter Arctic stratosphere from Michelson Interferometer for Passive Atmospheric Sounding limb emission spectra, J. Geophys. Res., 102, 16157-16168, 1997.

von Clarmann, T., Glatthor, N., Höpfner, M., Kellmann, S., Ruhnke, R., Stiller, G. P., Fischer, H., Funke, B., Gil-López, S., and López-Puertas, M.: Experimental Evidence of Perturbed Odd Hydrogen and Chlorine Chemistry After the October 2003 Solar Proton Events, J. Geophys. Res., 110, A09S45, https://doi.org/10.1029/2005JA011053, 2005.

von Clarmann, T., Höpfner, M., Kellmann, S., Linden, A., Chauhan, S., Funke, B., Grabowski, U., Glatthor, N., Kiefer, M., Schieferdecker, T., Stiller, G. P., and Versick, S.: Retrieval of temperature, $\mathrm{H}_{2} \mathrm{O}, \mathrm{O}_{3}, \mathrm{HNO}_{3}, \mathrm{CH}_{4}, \mathrm{~N}_{2} \mathrm{O}, \mathrm{ClONO}_{2}$ and $\mathrm{ClO}$ from MIPAS reduced resolution nominal mode limb emission measurements, Atmos. Meas. Tech., 2, 159-175, https://doi.org/10.5194/amt-2159-2009, 2009.

von Clarmann, T., Funke, B., López-Puertas, M., Kellmann, S., Linden, A., Stiller, G. P., Jackman, C. H., and Harvey, V. L.: The solar proton events in 2012 as observed by MIPAS, Geophys. Res. Lett., 40, 1-5, https://doi.org/10.1002/grl.50119, 2013.

von Hobe, M., Afchine, A., Barthel, J., Franke, H., Hrechanyy, S., Spelten, N., Tan, V., Winkler, U., and Stroh, F.: HALOX: An Instrument for the In-situ Measurement of $\mathrm{ClO}$ Dimer and Chlorine Nitrate, EGS - AGU - EUG Joint Assembly, 6-11 April 2003, Nice, France, provided by the SAO/NASA Astrophysics Data System, 3111 pp., 2003.

Wagner, G. and Birk, M.: New infrared spectroscopic database for chlorine nitrate, J. Quant. Spectrosc. Ra., 82, 443-460, https://doi.org/10.1016/S0022-4073(03)00169-9, 2003.

Wallington, T. J. and Cox, R. A.: Kinetics and product of the gasphase reaction of $\mathrm{ClO}$ with $\mathrm{NO}_{2}$, J. Chem. Soc., Faraday Trans. 2, 82, 275-289, https://doi.org/10.1039/F29868200275, 1986.

Wang, S. and Pratt, K. A.: Molecular halogens above the Arctic snowpack: emissions, diurnal variations, and recycling mechanisms, J. Geophys. Res.-Atmos., 122, 11991-12007, https://doi.org/10.1002/2017JD027175, 2017.

Waymark, C., Walker, K. A., Boone, C. D., and Bernath, P. F.: ACEFTS version 3.0 data set: validation and data processing update, Ann. Geophys.-Italy, 56, 6339, https://doi.org/10.4401/ag-6339, 2013.

Weaver, A., Loewenstein, M., Podolske, J. R., Strahan, S. E., Proffitt, M. H., Aikin, K., Margitan, J. J., Jonsson, H. H., Brock, C. A., Wilson, J. C., and Toon, O. B.: Effects of Pinatubo aerosol on stratospheric ozone at mid-latitudes, Geophys. Res. Lett., 20, 2515-2518, 1993

Webster, C. R., May, R. D., Michelsen, H. A., Scott, D. C., Wilson, J. C., Jonsson, H. H., Brock, C. A., Dye, J. E., Baumgardner, D., Stimpfle, R. M., Koplow, J. P., Margitan, J. J., Proffitt, M. H., Jaeglé, L., Herman, R. L., Hu, H., Flesch, G. J., and Loewenstein, M.: Evolution of $\mathrm{HCl}$ concentrations in the lower stratosphere from 1991 to 1996 following the eruption of Mt. Pinatubo, Geophys. Res. Lett., 25, 995-998, 1998.

Wegner, A., Stiller, G. P., von Clarmann, T., Maucher, G., Blumenstock, T., and Thomas, P.: Sequestration of $\mathrm{HNO}_{3}$ in polar stratospheric clouds and chlorine activation as monitored by groundbased Fourier transform infrared solar absorption measurements, J. Geophys. Res., 103, 22181-22200, 1998.

Wetzel, G., Oelhaf, H., Friedl-Vallon, F., Kleinert, A., Lengel, A., Maucher, G., Nordmeyer, H., Ruhnke, R., Nakajima, H., Sasano, Y., Sugita, T., and Yokota, T.: Intercomparison and validation of ILAS-II version 1.4 target parameters with MIPAS-B measurements, J. Geophys. Res., 111, D11S06, https://doi.org/10.1029/2005JD006287, 2006

Wetzel, G., Sugita, T., Nakajima, H., Tanaka, T., Yokota, T., FriedlVallon, F., Kleinert, A., Maucher, G., and Oelhaf, H.: Technical Note: Intercomparison of ILAS-II version 2 and 1.4 trace species with MIPAS-B measurements, Atmos. Chem. Phys., 8, 11191126, https://doi.org/10.5194/acp-8-1119-2008, 2008.

Wetzel, G., Oelhaf, H., Kirner, O., Ruhnke, R., Friedl-Vallon, F., Kleinert, A., Maucher, G., Fischer, H., Birk, M., Wagner, G., and Engel, A.: First remote sensing measurements of $\mathrm{ClOOCl}$ along with $\mathrm{ClO}$ and $\mathrm{ClONO}_{2}$ in activated and deactivated Arctic vortex conditions using new $\mathrm{ClOOCl}$ IR absorption cross sections, Atmos. Chem. Phys., 10, 931-945, https://doi.org/10.5194/acp10-931-2010, 2010.

Wetzel, G., Oelhaf, H., Kirner, O., Friedl-Vallon, F., Ruhnke, R., Ebersoldt, A., Kleinert, A., Maucher, G., Nordmeyer, H., and Orphal, J.: Diurnal variations of reactive chlorine and nitrogen oxides observed by MIPAS-B inside the January 2010 Arctic vortex, Atmos. Chem. Phys., 12, 6581-6592, https://doi.org/10.5194/acp-12-6581-2012, 2012.

Wetzel, G., Oelhaf, H., Friedl-Vallon, F., Kleinert, A., Maucher, G., Nordmeyer, H., and Orphal, J.: Long-term intercomparison of MIPAS additional species $\mathrm{ClONO}_{2}, \mathrm{~N}_{2} \mathrm{O}_{5}, \mathrm{CFC}-11$, and CFC12 with MIPAS-B measurements, Ann. Geophys.-Italy, 56, 6329, https://doi.org/10.4401/ag-6329, 2013.

Wilson, J. C., Jonsson, H. H., Brock, C. A., Toohey, D. W., Avallone, L. M., Baumgardner, D., Dye, J. E., Poole, L. R., Woods, D. C., DeCoursey, R. J., Osborn, M., Pitts, M. C., Kelly, K. K., Chan, K. R., Ferry, G. V., Loewenstein, M., Podolske, J. R., and Weaver, A.: In situ observations of aerosol and chlorine monoxide after the 1991 eruption of Mount Pinatubo: Effect of reactions on sulfate aerosol, Science, 261, 1140-1143, 1993. 
Woiwode, W., Oelhaf, H., Gulde, T., Piesch, C., Maucher, G., Ebersoldt, A., Keim, C., Höpfner, M., Khaykin, S., Ravegnani, F., Ulanovsky, A. E., Volk, C. M., Hösen, E., Dörnbrack, A., Ungermann, J., Kalicinsky, C., and Orphal, J.: MIPAS-STR measurements in the Arctic UTLS in winter/spring 2010: instrument characterization, retrieval and validation, Atmos. Meas. Tech., 5, 1205-1228, https://doi.org/10.5194/amt-5-1205-2012, 2012.

Wolff, M. A., Kerzenmacher, T., Strong, K., Walker, K. A., Toohey, M., Dupuy, E., Bernath, P. F., Boone, C. D., Brohede, S., Catoire, V., von Clarmann, T., Coffey, M., Daffer, W. H., De Mazière, M., Duchatelet, P., Glatthor, N., Griffith, D. W. T., Hannigan, J., Hase, F., Höpfner, M., Huret, N., Jones, N., Jucks, K., Kagawa, A., Kasai, Y., Kramer, I., Küllmann, H., Kuttippurath, J., Mahieu, E., Manney, G., McElroy, C. T., McLinden, C., Mébarki, Y., Mikuteit, S., Murtagh, D., Piccolo, C., Raspollini, P., Ridolfi, M., Ruhnke, R., Santee, M., Senten, C., Smale, D., Tétard, C., Urban, J., and Wood, S.: Validation of $\mathrm{HNO}_{3}, \mathrm{ClONO}_{2}$, and $\mathrm{N}_{2} \mathrm{O}_{5}$ from the Atmospheric Chemistry Experiment Fourier Transform Spectrometer (ACE-FTS), Atmos. Chem. Phys., 8, 3529-3562, https://doi.org/10.5194/acp-8-3529-2008, 2008.

Yokelson, R. J., Burkholder, J. B., Goldfarb, L., Fox, R. W., Gilles, M. K., and Ravishankara, A. R.: Temperature dependent rate coefficient for the $\mathrm{Cl}+\mathrm{ClONO}_{2}$ reaction, J. Phys. Chem., 99, 13976-13983, https://doi.org/10.1021/j100038a032, 1995.

Yudin, V. A., Geller, M. A., Khattatov, B. V., Douglass, A. R., Cerniglia, M. C., Waters, J. W., Elson, L. S., Roche, A. E., and Russell III, J. M.: A UARS study of lower stratospheric polar processing in the early stages of northern and southern winters, J. Geophys. Res., 102, 19137-19148, 1997.
Yung, Y. L., Pinto, J. P., Watson, R. T., and Sander, S. P.: Atmospheric Bromine and Ozone Perturbations in the Lower Stratosphere, J. Atmos. Sci., 37, 339-353, 1980.

Zahniser, M. S., Chang, J., and Kaufman, F.: Chlorine nitrate: Kinetics of formation by $\mathrm{ClO}+\mathrm{NO}_{2}+\mathrm{M}$ and of reaction with OH, J. Chem. Phys., 67, 997-1003, 1977.

Zander, R. and Demoulin, P.: Spectroscopic evidence for the presence of the $v_{4}$-Q branch of chlorine nitrate $\left(\mathrm{ClONO}_{2}\right)$ in groundbased infrared solar spectra, J. Atmos. Chem., 6, 191-200, https://doi.org/10.1007/BF00053855, 1988.

Zander, R., Rinsland, C. P., Farmer, C. B., Brown, L. R., and Norton, R. H.: Observation of several chlorine nitrate $\left(\mathrm{ClONO}_{2}\right)$ bands in stratospheric infrared spectra, Geophys. Res. Lett., 13, 757-760, https://doi.org/10.1029/GL013i008p00757, 1986.

Zander, R., Gunson, M. R., Foster, J. C., Rinsland, C. P., and Namkung, J.: Stratospheric $\mathrm{ClONO}_{2}, \mathrm{HCl}$, and $\mathrm{HF}$ concentration profiles derived from Atmospheric Trace Molecule Spectroscopy Experiment Spacelab 3 observations: An update, J. Geophys. Res., 95, 20519-20525, https://doi.org/10.1029/JD095iD12p20519, 1990. 